NBER WORKING PAPER SERIES

\title{
SUPPLY- AND DEMAND-SIDE FACTORS IN GLOBAL BANKING
}

\author{
Mary Amiti \\ Patrick McGuire \\ David E. Weinstein \\ Working Paper 23536 \\ http://www.nber.org/papers/w23536 \\ NATIONAL BUREAU OF ECONOMIC RESEARCH \\ 1050 Massachusetts Avenue \\ Cambridge, MA 02138 \\ June 2017
}

Also published as BIS working paper no. 639. The authors thank Jakub Demski and Scott Marchi for excellent research assistance, and Mark Carlson, Linda Goldberg, Sebnem Kalemli-Ozcan, Catherine Koch, Bruno Tissot, Philip Wooldridge, participants at the 3rd BIS-CGFS workshop on "Research on global financial stability: the use of the BIS international and financial statistics" (7 May 2016), participants at the BIS-Bank Negara Malaysia conference on "Financial systems and the Real Economy (18-19 October 2016, Kuala Lumpur) and seminar participants at De Nederlandsche Bank (20 Sept 2016) for comments and discussion. David Weinstein also thanks the Bank of International Settlements for providing a research fellowship to complete this research. The views expressed in this paper are those of the authors and not necessarily those of the BIS, the Federal Reserve Bank of New York, the Federal Reserve System, or the National Bureau of Economic Research.

NBER working papers are circulated for discussion and comment purposes. They have not been peer-reviewed or been subject to the review by the NBER Board of Directors that accompanies official NBER publications.

(C) 2017 by Mary Amiti, Patrick McGuire, and David E. Weinstein. All rights reserved. Short sections of text, not to exceed two paragraphs, may be quoted without explicit permission provided that full credit, including $(\subset$ notice, is given to the source. 
Supply- and Demand-side Factors in Global Banking Mary Amiti, Patrick McGuire, and David E. Weinstein

NBER Working Paper No. 23536

June 2017

JEL No. F34,G01,G21

\section{ABSTRACT}

What is the role for supply and demand forces in determining movements in international banking flows? Answering this question is crucial for understanding the international transmission of financial shocks and formulating policy. This paper addresses the question by using the method developed in Amiti and Weinstein (forthcoming) to exactly decompose the growth in international bank credit into common shocks, idiosyncratic supply shocks and idiosyncratic demand shocks for the period 2000-2016. A striking feature of the global banking flows data can be characterized by what we term the "Anna Karenina Principle": all healthy credit relationships are alike, each unhealthy credit relationship is unhealthy in its own way. During non-crisis years, bank flows are well-explained by a common global factor and a local demand factor. But during times of crisis flows are affected by idiosyncratic supply shocks to a borrower country's creditor banks. This has important implications for why standard models break down during crises.

Mary Amiti

Microeconomic Studies Function

Federal Reserve Bank of New York

33 Liberty St

New York, NY 10045-0001

Mary.Amiti@ny.frb.org

Patrick McGuire

Bank for International Settlements

Basel, Switzerland 4051

patrick.mcguire@bis.org
David E. Weinstein

Columbia University

Department of Economics

420 W. 118th Street

MC 3308

New York, NY 10027

and NBER

dew35@columbia.edu 


\section{Introduction}

The question of what drives international banking flows is of central importance for policymakers and economists trying to understand the international transmission of banking crises. In answering this question, researchers have identified a large number of plausible demand and supply factors. However, these answers remain incomplete in the sense that regression evidence always involves a residual that typically accounts for the vast majority of the variance. For example, how much weight should policy makers place on a finding that, say, interest rate differentials across countries are correlated with capital flows when the empirical model used to produce this result is able to explain only a tiny share of the aggregate movements in these flows? Such problems become even more severe in periods of financial stress, when statistical relationships that seem strong in normal times break down. This fact makes it very difficult to match theory to data.

This paper solves this problem by providing a methodology, based on Amiti and Weinstein (forthcoming), that generates an exact decomposition of the growth in global bank flows into three components. First, there is a "common" shock that affects all banking relationships and captures common forces. Second, there is a bankingsystem, or "supply", shock that captures how idiosyncratic shifts in a banking system's credit supply behaviour. Third, there is a borrower country, or "demand", shock that captures idiosyncratic shifts in a destination's borrowing behaviour. ${ }^{2}$ This method is appropriate for all models of global banking behaviour that specify credit growth from a bank to a borrower as a linear combination of a source banking system shock, a destination shock and possibly a source-destination interaction term.

We apply this methodology to the BIS Consolidated Banking Statistics (CBS), which track the consolidated foreign claims (ie loans, holdings of debt securities and other financial claims) of banks headquartered in 31 reporting countries on counterparties in more than 200 countries. Global bank claims are highly concentrated in only a handful of banking systems and a somewhat larger set of counterparty (borrower) countries. This concentration impacts the data in two important ways. First, the vast majority of bilateral credit flows are small compared to the aggregate flow of the typical banking system, which makes it problematic to use standard regression techniques to infer aggregate behaviour. Second, the small number of large banking systems means that idiosyncratic credit supply shocks in one banking system can have aggregate implications.

Most important from the perspective of policy makers today, the estimates offer an up-to-date decomposition of the growth in foreign claims. This is particularly important for monitoring bank credit to borrowers in emerging economies. For example, while global claims growth slowed in 2015 and 2016, the contraction in credit to emerging Asia and emerging Europe - to China and Russia in particular - was severe. Negative supply shocks, which in part reflect a contraction in European banks' global balance sheets, contributed somewhat. But the estimates presented here suggest that these countries are unique, with borrower country characteristics (ie demand shocks) accounting for virtually all of the decline.

In order to produce these estimates, we first adjust the data in two ways. The publicly available CBS contain numerous breaks in series, due to bank mergers or changes in reporting methodology, that produce wild swings in the series that swamp the true variation. A second problem arises because banks' bilateral positions are typically denominated in many currencies but are expressed in US dollars when reported to the BIS. Exchange rate movements change the relative value of the underlying currencies and thus induce changes in outstanding stocks that do not signify the actual extension or withdrawal of credit. We correct the data to render consistently measured supply and demand shocks to the growth rates of bank credit. ${ }^{3}$

To assess whether the estimated supply and demand shocks are meaningful in an economic sense, we compare them to measures of banking system and country health during periods of known stress. In some cases, these comparisons are little more than a check against widely-known events, for example the near bankruptcy and subsequent restructuring of the major Japanese banks in 2001-02, Argentina's sovereign default in 2001, and sanctions on Russia in 2014. In other cases, we correlate the estimated shocks with outside measures of bank health and balance sheet structure, for example banks' reliance on core funding (ie deposits) prior to the 2007-09 financial crisis and their total losses incurred during the crisis. In virtually every case, the estimated shocks align with our priors about the sign and magnitude suggested by these outside measures.

Our results generate several new insights about global banking flows. First, a striking feature of the data can be characterized by what we term the "Anna Karenina Principle": all healthy credit relationships are alike, each unhealthy credit relationship is unhealthy in its own way. We demonstrate this principle in a simple way. During non-crisis years, bank flows are well-explained by a common global factor that affects all banking

Note, however, that the terms "supply" and "demand" are defined in terms of factors that are explainable by a supplier-time fixed effect or a borrower-time fixed effect. Thus, if all banking systems cease lending to a particular country, we will call that a demand shock because it is explainable by some characteristic of that destination even though the reason might be that all banking systems refuse to lend to that borrower.

3 Cerrutti (2015) and McGuire and von Peter (2016) make similar adjustments. 
systems and borrower countries, and a local demand factor. But during times of crisis, aggregate bank credit, and credit to particular countries, are importantly affected by idiosyncratic supply forces that depend on the various shocks that affect a borrower's major credit suppliers. Thus, during times of crisis, two countries with identical demand for credit will receive different amounts of credit depending on the relative health of the banking systems that serve them. During crisis periods, flows can only be explained if one knows not only global supply and local demand but also what is happening to each of the banking systems that are supplying credit to a country. This has important implications for why standard models break down during crises.

Second, during the 2007-09 global financial crisis (GFC), supply shocks contributed significantly to the contraction in credit to almost all borrower countries. This is consistent with earlier studies (eg Cetorelli and Goldberg (2011)) that linked shocks to banks' balance sheets from losses on structured finance products and the turbulence in US dollar funding markets to a diversion of credit. Similarly, during the euro area sovereign crisis which started in mid-2010 and continued in fits and starts thereafter, common shocks were less important than idiosyncratic supply and demand shocks. The severe downturn in global banks' foreign claims on the key countries involved in the crisis - Greece, Italy, Ireland, Portugal and Spain - were unique to these countries, and hence the negative demand-side shocks were particularly severe. Negative supply shocks did play a role too, as banks headquartered in some of these countries saw large contractions in their foreign credit, some of which had been directed to other borrower countries in crisis. This decomposition provides policy makers with invaluable information on the underlying forces of international banking flows

\section{Relation to prior work}

There is a wide literature on how the 2007-2009 financial crisis was transmitted across countries. Several prominent studies focus on countries' external positions, as captured in the balance of payments statistics, to show how countries' pre-crisis positions affected their adjustment in the wake of the crisis (Lane and MilesiFerretti (2012, 2014), Milesi-Ferretti and Tille (2011)). Our primary interest here is the subset of this work that focuses on global bank credit.

Much of this makes use of the BIS international banking statistics, and relies on panel regressions of the growth in banks' bilateral claims. A host of creditor-banking system and borrower-country control variables, and fixed effects for both, are often used to tease out the supply- and demand-side forces (sometimes termed "push" or "pull" factors). ${ }^{4}$ For example, McGuire and Tarashev (2008) used panel OLS regressions to investigate how deterioration in banks' balance sheets contributed to the subsequent slowdown in claim growth in the initial phases of the 2007-2009 global financial crisis. Using a similar framework, Cerutti (2015) examined banks' cross-border exposures throughout the crisis, after making adjustments for the role of subsidiaries in the banks' global operations. Takáts (2010) and Avdjiev et al (2012) analysed cross-border bank flows to emerging economies and found that home-country (ie supply) factors generally contributed to crossborder credit growth, but their importance increased sharply during the 2008-09 financial crisis and again during the euro area sovereign crisis. And in an oft-cited study, Cetorelli and Goldberg (2011) examined how shocks to banks' US dollar funding during the crisis contributed to the contraction in claims on emerging economies. Their empirical methodology is a variant of that in the seminal paper by Khwaja and Mian (2008), whose structural model yields an estimating equation where fixed effects control for individual firm-level demand-side shocks.

Several relevant papers have looked beyond the 2007-09 crisis period. Bruno and Shin (2014) develop a model of how leverage in internationally-active banks interacts with local banks in the transmission of financial conditions across borders, and then use panel regression analysis on the BIS Locational Banking Statistics to test the predictions of their model. Similar in spirit, Cerutti et al. (2017) use the same data to examine the determinants of global liquidity and find that investor uncertainty, US monetary policy and bank conditions in large countries all contribute to cross-border banking flows. Kalemli-Ozcan et al (2013) find that increases in bilateral banking linkages are associated with more divergent output cycles during non-crisis periods but not during crisis periods, suggesting that financial crises induce co-movement among more financially integrated countries. Finally, Avdjiev and Takáts (2014) analyse the slowdown in cross-border claims on emerging economies during the so-called "taper tantrum" in May 2013, when the Federal Reserve hinted that it might end its quantitative easing, and highlighted the central role of the US dollar in bank credit to many economies.

Most empirical studies to date have been successful in identifying particular drivers that can credibly be attributed to supply- or demand-side shocks. However, those that rely on panel regressions of bilateral banking linkages generally lack a framework of supply and demand factors that can account for the observed behaviour

See Koepke (2015) for a review of the literature on "push" and "pull" factors in capital flows to emerging economies, and Fratzscher (2012) for an application at the level of individual mutual funds. 
in aggregate claim growth, as evidenced by $R^{2}$ values that often explained less than 10 percent of the variation. In some cases, the failure to adjust the data for exchange rate movements and breaks in series, as discussed in Section 4 below, was a contributing factor. But, arguably the main reason why existing models have fared poorly in this regard is that they do not take into account the extreme heteroscedasticity in the bilateral growth rates in their samples (also discussed in Sections 4 and 5 below).

This problem is particularly acute when changes in the aggregate level of the dependent variable (ie summed across all banking systems and borrower countries) are driven by changes in only a few underlying observations, ie those where the bilateral levels are large. For example, a 2\% increase in a $\$ 500$ billion bilateral claim position contributes much more to the change in global claims than does a $300 \%$ increase in a $\$ 0.5$ billion position. Yet, in a typical panel regression where growth rates are used as the dependent variable, both observations are given equal weight in the determination of the regression coefficients. And as a result, the estimated coefficients reflect the "average effect" across all observations, without taking into account each observation's unique contribution to the growth in aggregate claims. While some authors have mitigated this problem by weighting log-growth specifications, this procedure does not resolve the problem, which is why we use an alternative approach.

\section{Empirical framework}

We use an estimation technique introduced in Amiti and Weinstein (forthcoming) to address this problem. We briefly review the methodology here, but interested readers are encouraged to consult the original paper for a full derivation of the estimating equation and formal proofs of the statements in this section. We begin with two alternative specifications, with the dependent variable defined as (1) the percentage change or (1') the log change in the bilateral stock of claims $(L)$ reported by banking system $b$ on borrower country $c$. These equations relate the growth in claims to time-varying "supply" shocks that affect creditor banks $\left(\beta_{b, t}\right)$ and time-varying "demand" shocks that affect borrower countries $\left(\alpha_{c, t}\right)$. $^{5}$

$$
\begin{gathered}
\frac{L_{b, c, t}-L_{b, c, t-1}}{L_{b, c, t-1}}=\alpha_{c, t}+\beta_{b, t}+\varepsilon_{b, c, t} \\
\Delta \ln L_{b, c, t}=\alpha_{c, t}+\beta_{b, t}+\varepsilon_{b, c, t}
\end{gathered}
$$

One strategy is to estimate equations (1) or (1') in a simple OLS regression of the bilateral growth in claims on a full set of time-varying banking system and borrower country fixed effects. This approach, however, suffers from two problems. First, OLS will produce estimates that cannot be perfectly aggregated to exactly yield banking systems', borrower countries', or total claim growth rates even if all bilateral relationships are maintained in periods $t$ and $t-1$. Second, OLS can yield biased estimates of the supply and demand shocks in any data sample where new bilateral links form (eg, when a banking system starts or resumes lending to a particular country) since, for such observations, $L_{b, c, t-1}$ is zero and $\Delta \ln L_{b, c, t}$ is undefined. Hence the bilateral growth rate for the period is undefined. ${ }^{6} \mathrm{We}$ address these two problems sequentially.

The basic intuition for the aggregation problem that arises with OLS estimation of equation (1) is that it weights all of the observations equally, which would be appropriate if one wanted an estimate of the unweighted arithmetic averages of claims growth rates. Similarly, estimation of equation (1') is appropriate if one wanted to estimate an unweighted geometric average of claims in period $t$ divided by the geometric average of claims in period $t-1$. Since there is no clear mapping between unweighted arithmetic or geometric means of growth rates and total claim growth rates, neither method yields parameter estimates that can be aggregated to yield the growth in aggregate claims, or even the growth in total claims of a particular banking system or on a particular country. Such estimates require an appropriate specification and weighting system.

Amiti and Weinstein (forthcoming) prove that one can exactly obtain estimates of banking system (supply) and borrower country (demand) shocks $\left(\beta_{b, t}, \alpha_{c, t}\right)$ that will aggregate to match the growth rate of pre-existing claims (ie claims for which $L_{b, c, t-1}>0$ ), by weighting the data with the lagged claim level. Weighted Least Squares (WLS) estimation of equation (1) produces unique estimates (up to a numéraire) of the supply and demand shocks that must aggregate to match the growth in aggregate claims. In order to deal with new bilateral relations, such as cases where a banking system starts (or resumes) a claim relationship with a borrower country, the moment equations are modified. That is, summing over all bilateral pairs instead of only those that existed in

Khwaja and Mian (2008) derive a version of this equation from a structural model in which banks face positive marginal financing costs and decreasing returns to capital as aggregate borrowing increases.

6 Coefficients estimated with OLS are unbiased for the subset of existing bilateral claims, but often what is of interest is the behaviour of aggregate credit growth. Thus, in data samples where bilateral links regularly disappear and reappear, simple OLS is of little use. 
the previous period guarantees that the supply and demand shocks exactly match the growth in total claims of each banking system and the growth in total claims on each borrower country.

After some algebra, Amiti and Weinstein show that the supply and demand shocks affecting each bankborrower pair can be expressed as relative to the median bilateral claim growth rate. Thus, our renormalized constant, $\hat{c}_{t}$, will equal the median bilateral claim growth rate, which we term the "common shock", and $\hat{\beta}_{b, t}$ and $\hat{\alpha}_{c, t}$ will equal the idiosyncratic banking system (supply) and borrower country (demand) shocks less the common shock.

With these shocks in hand, it is possible exactly decompose the growth in a banking system's aggregate claims $\left(D_{\mathrm{ct}}\right)$ into three components:

$$
\mathrm{D}_{\mathrm{bt}}=\hat{c}_{t}+\hat{\beta}_{b, t}+\sum_{c}\left(\phi_{b, c, t-1} \hat{\alpha}_{c, t}\right)
$$

where $\hat{c}_{t}$ is a "common shock" which affects all bilateral pairs and cannot be separated into a demand or supply shock; $\hat{\beta}_{b, t}$, is an idiosyncratic banking system supply shock, relative to the common shock; and $\sum_{c}\left(\phi_{b, c, t-1} \hat{\alpha}_{c, t}\right)$ is a banking system' idiosyncratic demand shock, which captures the aggregate impact of each of the demand shocks in the borrower countries on which the banking system has claims, and where the weights are defined as $\phi_{b, c, t-1} \equiv \frac{L_{b, c, t-1}}{\sum_{c} L_{b, c t-1}}$. Similarly, we can exactly decompose the growth in aggregate claims on a particular borrower country into a common shock, $\hat{c}_{t}$, an idiosyncratic demand shock $\left(\hat{\alpha}_{c, t}\right)$, and the borrower's idiosyncratic supply shock, $\sum_{b}\left(\theta_{b, c, t-1} \hat{\beta}_{b, t}\right)$, which is a weighted average of the supply shocks to the borrower's creditor banks where the weights are defined as $\theta_{b, c, t-1} \equiv \frac{L_{b, c, t-1}}{\sum_{b} L_{b, c, t-1}}$ :

$$
\mathrm{D}_{\mathrm{ct}}=\hat{c}_{t}+\hat{\alpha}_{c, t}+\sum_{b}\left(\theta_{b, c, t-1} \hat{\beta}_{b, t}\right)
$$

Equations (2) and (3) can be used to decompose the growth in claims of a banking system or the growth in claims on a borrower country in terms of common (ie global) shocks, and idiosyncratic shocks arising from the fortunes of the suppliers and demanders of credit relative to that banking system or destination. Importantly, the weights $\left(\phi_{b, c, t-1}, \theta_{b, c, t-1}\right)$ vary by bank-borrower pair. Thus, a shock to one banking system need not affect all borrowers equally, and similarly, a shock to one borrower country need not reduce claims from all creditor banks equally.

We also can exactly aggregate across banking systems to see how these shocks affect the growth in aggregate claims. In order to do this, we simply weight each claim growth rate by that banking system's share in total claims $\left(w_{b, t-1} \equiv \sum_{c} L_{b, c, t-1} / \sum_{b, c} L_{b, c, t-1}\right)$ and sum across all banking systems to generate

$$
\mathrm{D}_{\mathrm{t}} \equiv \sum_{b} w_{b, t-1} D_{b, t \mathrm{t}}=\hat{c}_{t}+\sum_{b} w_{b, t-1} \hat{\beta}_{b, t}+\sum_{b} w_{b, t-1} \sum_{c}\left(\phi_{b, c, t-1} \hat{\alpha}_{c, t}\right)
$$

Equation (4) exactly decomposes total claim growth $\left(D_{t}\right)$ at time $t$ into three terms: a common shock, a "granular" bank shock, and a "granular" demand shock. The granular bank shock measures how idiosyncratic shocks to large banking systems affect the growth in aggregate claims supply. Obviously, if all banking systems were small $\left(w_{b, t-1} \approx 0\right)$, the law of large numbers implies that the idiosyncratic shocks would cancel and this term would not matter. Thus, the granular bank shock term will be non-zero if lending is "granular" - ie, the share of global claims by some banking systems $\left(w_{b, t-1}\right)$ differ substantially from zero (ie they are granular) and idiosyncratic shocks to these banking systems are non-zero $\left(\hat{\beta}_{b, t} \neq 0\right)$. Similarly, the last term describes the granular demand shock. This term will vary substantially if some borrowers are sizeable, so that $\phi_{b, c, t-1}$ differs significantly from zero, and some of those borrowers have non-zero idiosyncratic demand shocks $\left(\hat{\alpha}_{c, t}\right)$.

\section{Data and summary statistics}

The CBS capture reporting banks' globally consolidated foreign claims, with information about the location (country) and type of counterparties. However, the ability of researchers to use these data to understand actual bank credit behaviour has been limited by the violent jumps in claims that arise from methodological changes (ie "breaks in series") and that occur solely because the exchange rates for the currencies in which the claims were denominated moved. One of the differences between this paper and most prior research is the use of a confidential version of the BIS Consolidated Banking Statistics (CBS) that enables us to eliminate the substantial measurement error that can arise from computing bilateral claim growth rates from the publicly available versions of these statistics.

This section describes these statistics, with details about how we corrected their shortcomings before using them in Section 5. We review (a) the degree to which global bilateral banking positions are concentrated in a relatively small number of bilateral linkages, which renders standard estimation based on bilateral growth rates problematic; (b) the various adjustments applied to these data to produce the growth rates used as inputs to the 
empirical analysis; and (c) the types of claims - cross-border vs locally booked claims - and the differences in their growth rates.

\subsection{Overview of the BIS consolidated banking statistics}

The CBS track the outstanding foreign claims of banks headquartered in 31 countries ("reporting countries") on more than 200 borrower countries. ${ }^{7}$ These quarterly data are not at the level of individual banks, but rather are aggregated at the level of internationally-active banks headquartered in a particular country (eg "US banks", "French banks", etc). ${ }^{8}$ But unlike other data sources that do provide bank-level detail (eg BankScope or SNL Financial), the CBS provide information about the location and sector of counterparties, which is essential for any analysis of how demand and supply factors affect the growth in international bank credit.

The basic unit in the CBS is “foreign claims" (FC). A reporting bank's foreign claims on a particular country and sector include any loans extended to counterparties there, and any holdings of debt and equity securities issued by these counterparties. ${ }^{9}$ Claims are reported on a consolidated basis. ${ }^{10}$ That is, claims on counterparties in a particular country include all cross-border claims booked by a bank's home offices and its offices in other countries, plus claims extended locally by that bank's affiliates (subsidiaries and branches) located in the borrower country. ${ }^{11}$ In other words, the nationality of a reporting banking system in the CBS, eg "US banks", is not indicative of the location of these banks' offices, eg "banks in the United States". 12 To take an example, a cross-border loan extended by the subsidiary of a US bank located in London to a manufacturer in Germany would be included in US banks' consolidated foreign claims on Germany, as would a loan extended from the same US bank's home office in the United States to a household in Germany. By contrast, on the borrower country side, it is the location of the immediate counterparty that matters irrespective of the nationality of the borrower. For example, a cross-border loan extended by a branch of a French bank located in London to the subsidiary of a German corporation located in the United States would be included in French banks' worldwide consolidated foreign claims on counterparties in the United States.

Foreign claims are broken down into two components: "international claims" (INTLC) and "local claims in local currencies" (LCLC). International claims on a particular borrower country $c$ are (a) all cross-border claims in all currencies booked by the reporting banks' offices worldwide plus (b) any locally-extended claims (ie claims booked by the reporting banks' affiliates in country $c$ ) in non-local currencies. Local claims in local currency are claims booked by reporting banks' affiliates located in host country $c$ vis-à-vis residents of country $c$ and denominated in the local currency of country $c .{ }^{13}$ So, for example, a euro-denominated loan booked by a French bank's subsidiary in London to a borrower in Germany would be classified as an international claim on Germany, as would a US dollar loan booked by a subsidiary in Germany of the same French bank to the same borrower. By contrast, a euro-denominated loan booked by this French bank's subsidiary in Germany to the same German borrower would be classified as a local claim in local currency.

\subsection{Concentration in banks' bilateral foreign claims}

Idiosyncratic shocks to particular banking systems would not matter in a world with many lenders and borrowers, each of whom had a trivial share of the total market. In this case, the law of large numbers would apply and idiosyncratic shocks would just cancel. However, the CBS data reveal that international bank positions are extremely concentrated in a handful of creditor banking systems and borrower countries (Graph 1, top panels). All banks combined reported a total of $\$ 25.6$ trillion in foreign claims spread across counterparties

7 In the analysis that follows, we exclude banks headquartered in Brazil, Greece, Ireland, Mexico and Norway due to data quality issues.

8 We use the CBS on an immediate counterparty basis (IC basis), which allocates claims to the country and sector where the contractual counterparty is located. These statistics are appropriate for analyzing the credit provided to particular countries. By contrast, the CBS on an ultimate risk basis (UR basis) allocates claims to the country and sector where the ultimate obligor resides, that is, after taking into account parent- and third-party guarantees, CDS protection bought, collateral and other credit hedges.

9 Claims do not include derivatives with a positive market value (from the reporting bank's perspective) with a contractual counterparty in the country. These are reported separately in the CBS (UR basis).

10 Banks' claims on residents of their home country have been included in the CBS only since 2013 Q4, and are thus not considered in this paper.

11 See Cerutti (2015) for a separate consideration of the role of branches and subsidiaries in the CBS.

12 See McCauley et al (2012), McGuire and von Peter (2012, 2016) and McGuire and Wooldridge (2005) for discussion of the CBS and the differences in reporting banking systems' organisational structure.

13 That is, FC = INTL + LCLC where INTL = cross-border claims (XBC) plus locally extended claims in non-local (foreign) currencies (LCFC). 
in 225 countries at end-Q3 2016. The top 5 banking systems accounted for more than half of this total, and the top ten for $84 \%$ (top left panel). Banks headquartered in Japan ("Japanese banks") reported the largest foreign claims positions at end-Q3 2016 (\$4 trillion), followed by UK and US banks" (\$3.1 trillion each) and French banks ( $\$ 2.7$ trillion). At the other end of the spectrum were Turkish banks ( $\$ 17$ billion), Chilean banks (\$11 billion) and Mexican banks (\$9 billion).

Banks' claims are also concentrated in only a few borrower countries. The median banking system reported outstanding claims on 154 countries at end-Q3 2016. But these claims were not evenly dispersed: the share of its total claims on its top five countries was 61 percent. This makes it clear that while some borrower countries are extremely important, the median value of claims from a banking system to a borrower constitutes only a tiny fraction of that banking system's total foreign claims. Banks' combined claims on a mere five countries made up almost half of the global total, with claims on the United States, United Kingdom and Germany accounting for more than one third (Graph 1, top right panel). The top 35 countries shown in the panel accounted for $90 \%$ of this total implying that only $10 \%$ of global claims were on the remaining 190 countries Moreover, there is substantial heterogeneity in where banks have claims. While most banking systems lend to virtually all of the 35 advanced economies, most of the variation in the number of borrower countries reflects the extent of banks' engagement with emerging economies.

\section{Concentration in foreign claims (FC)}

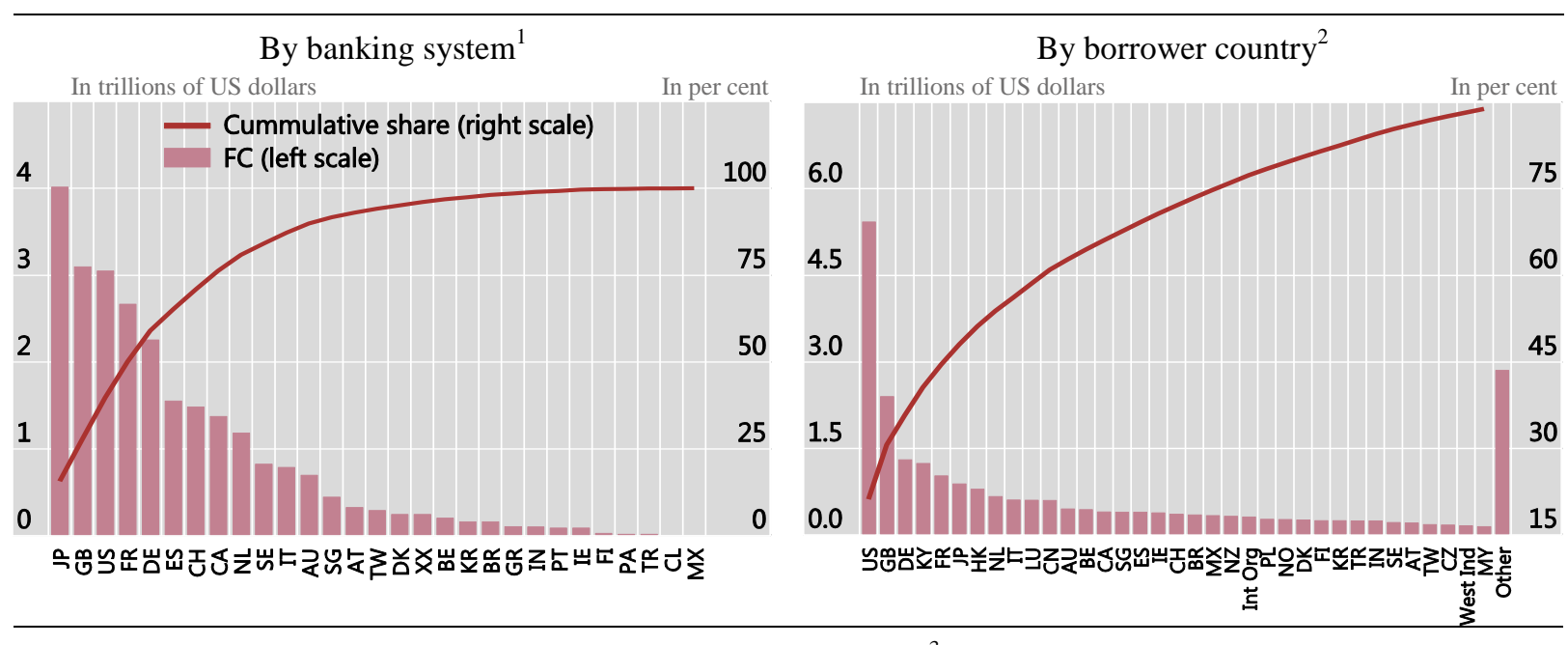

Bilateral observations ${ }^{3}$

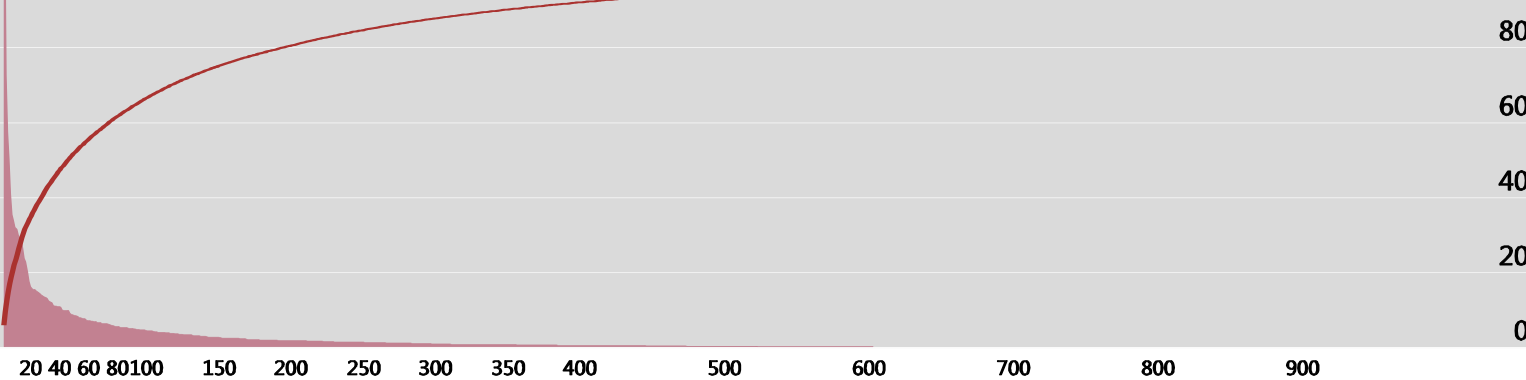

${ }^{1}$ Bars show the total claims on all borrower countries for the banking system listed on the $\mathrm{X}$-axis. Banking system "XX" is a combination of banks headquartered in Hong Kong, Luxembourg and Norway, which are masked due to confidentiality restrictions. The red line shows the cumulative share in all banking systems' claims on all borrower countries. ${ }^{2}$ Bars show all banking systems' combined claims on the borrower country listed on the $\mathrm{x}$-axis. The red line shows the cumulative share in all banking systems' claims on all borrower countries. ${ }^{3}$ Bars show bilateral claims (ie single banking system vis-à-vis a single borrower country) ordered from largest to smallest, while the red line depicts the cumulative share in all banking systems' claims on all borrower countries. The x-axis shows 962 observations (those >1\$ billion) out of 4,032 bilateral pairs with positive outstanding claims.

Source: BIS consolidated banking statistics (IC basis.

Concentration at the level of bilateral positions is even starker (Graph 1, lower panel). Overall, there were 4,032 positive bilateral links at end-Q3 2016. Dropping the 3,070 bilateral claims positions that were less than \$1 billion at end-Q3 2016 reduces the global total by a mere \$21 billion, leaving only the 962 bilateral links 
shown in the panel. The largest 44 bilateral links, or $1.1 \%$ of the total links, accounted for more than half of total foreign claims. ${ }^{14}$ The extreme concentration in bilateral positions helps explain why unweighted fixed effects estimation is likely to have limited explanatory power. In order to understand what is driving the growth in claims of a banking system, we need to know what is happening to its largest borrower countries, not the typical borrower.

This problem is exacerbated by the fact that the smallest claims positions typically have growth rates with the greatest volatility, resulting in them accounting for most of the variation in an unweighted regression. ${ }^{15} \mathrm{We}$ can see this fact in Graph 2, which shows the dispersion in bilateral growth rates separately for "big", "medium" and "small" bilateral pairs. ${ }^{16}$ The growth rates for big bilateral pairs tend to be much smaller and less volatile, which underscores our earlier point that movements in the typical bilateral claim stock are not representative or very informative about the aggregate movement.

\section{Dispersion in the year-over-year growth in bilateral foreign claims ${ }^{1}$}

In per cent
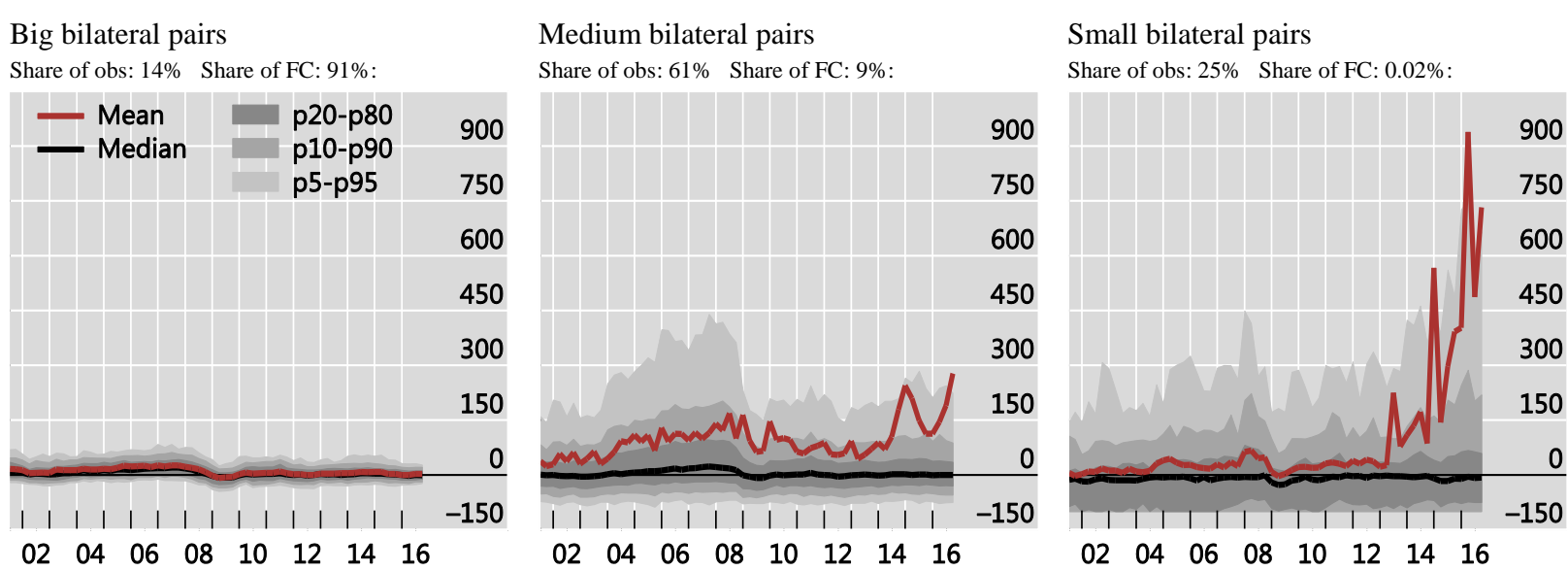

${ }^{1}$ Panels show the mean, median and selected percentile values (grey shaded area) of the year-over-year growth in foreign claims (adjusted for breaks in series and exchange rate movements). All bilateral (reporting bank vis-à-vis borrower country) observations are grouped based on the outstanding stock of foreign claims; "big" observations are those were the outstanding stock of foreign claims is greater than the $75^{\text {th }}$ percentile value for the sample as a whole, "small" observations are those that are below the $45^{\text {th }}$ percentile value, and "medium" observations are all others not classified as "big" or "small".

Source: BIS consolidated banking statistics (IC basis); BIS locational banking statistics; national data; authors' calculations.

\subsection{Adjustments to year-over-year growth rates}

Ideally, the input to the empirical analysis in Section 5 would be the growth in actual credit provided by each reporting banking system to borrowers in each country. Such credit flow data would perfectly capture banks' choices about when and to whom to extend new credit, independent of redemptions or the maturation of existing positions. However, such data are not available in the CBS. Instead, we rely on the year-over-year growth in the stock of outstanding foreign claims as a proxy for this ideal measure. In its unadjusted form, this proxy captures any actual increases or decreases in credit plus additional sources of variation that are not directly related to actual credit flows. These include (a) valuation effects that arise as firms mark up or down their debt securities holdings that are subject to mark-to-market accounting, or write down their loans that are held at book value; (b) valuation effects that arise from exchange rate movements; and (c) "breaks in series" in the underlying data.

We make two adjustments to the raw bilateral claims stocks to generate a proxy that better approximates the growth in actual credit provided (see Appendix A.2 for details). The first is a correction for "breaks in series", which can arise for various reasons but typically occur when there are bank mergers across jurisdictions,

14 Even if restricted to claims on emerging economies only, the sample is still concentrated: $14 \%$ of the resulting 2,688 observations at end-Q3 2016 captured $95 \%$ of foreign claims on all of them.

15 This reflects the fact that foreign claims, in particular their cross-border component, are not atomistic. For example, Cerutti et al (2015) report that the average deal size for syndicated loans, which constitute a substantial portion of claims in the CBS, fluctuated around $\$ 400$ million between 2000 and 2012 for borrowers in advanced economies; for those in emerging economies, average deal size rose from roughly $\$ 200$ million in 2000 to $\$ 300$ million in 2007 . The discrete nature of claims means that the booking of a new loan, or the maturation of an old loan, generate significant jumps in total outstanding positions when claims stocks are small. By weighting observations, the empirical methodology outlined in Section 2 and applied in Section 4 tackles this problem head on.

16 These growth rates have been adjusted for breaks in series and exchange rate movements as described in Section 3.3 below. 
or when a reporting country changes its reporting methodology or adds/removes banks from the population of reporting banks. ${ }^{17} \mathrm{~A}$ second adjustment is a correction for valuation effects that arise from exchange rate movements. Bilateral claims positions tend to be denominated in multiple currencies but are reported to the BIS expressed in US dollars. Large movements in exchange rates, like those that occurred in the wake of the collapse of Lehman Brothers, induce correspondingly large changes in outstanding claims stocks that are not indicative of either new credit extended or credit withdrawn. ${ }^{18}$

The effects of both of these corrections are illustrated in Graph 3. The outstanding stock of all banking systems' combined claims on various country groups is shown as the shaded area in each panel. The dotted black lines depict the year-over-year growth in these stocks, unadjusted for breaks in series and exchange rate movements. The dashed black lines show these growth rates after adjusting for breaks in series only, and the solid red lines show the growth rates after an additional correction for exchange rate movements. These adjustments make a noticeable difference. In particular, the unadjusted growth rate tended to be higher prior to the crisis, when the U.S. dollar depreciated against many currencies. By contrast, the adjusted growth rate shows a far less dramatic move into negative territory during the crisis. This difference primarily reflects the massive

\section{Adjusted year-over-year growth in foreign claims, by borrower region}

Left scale: in trillions of US dollars; right scale: in per cent
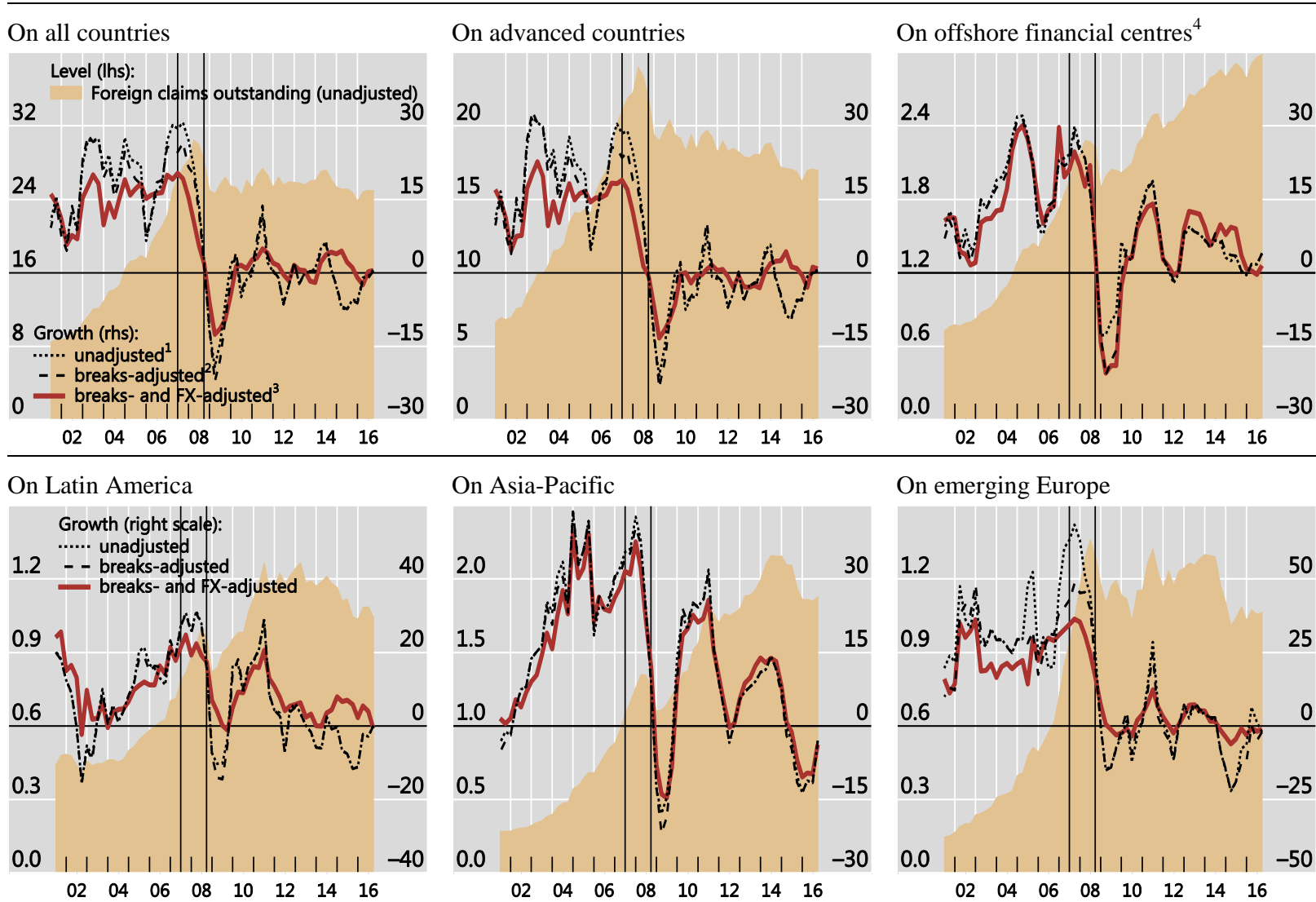

Note: Vertical black lines indicate end-Q2 2007 and end-Q3-2008.

${ }^{1}$ Growth in foreign claims without adjustments for breaks-in-series or exchange rate movements. ${ }^{2}$ Growth in foreign claims after adjustments for breaks-in-series only. ${ }^{3}$ Growth in foreign claims after adjustments for breaks-in-series and exchange rate movements. ${ }^{4}$ Includes Cayman Islands, Hong Kong, Singapore, Guernsey, Jersey, Isle of Man and other offshore financial centres.

Source: BIS consolidated banking statistics (IC basis); BIS locational banking statistics; national data; authors' calculations

17 For example, in 2005, Unicredit, an Italian bank, bought HypoVereinsbank (HVB), a German bank. As a result, all foreign claims booked by the latter disappeared from German banks' consolidated foreign claims and appeared in Italian banks' claims. A similar issue arose in 2009 Q1 when four US investment banks were converted to depository institutions and thus included for the first time in the population of US banks reporting in the CBS (see Avdjiev and Upper (2010) for discussion).

18 The CBS provide only a partial breakdown by currency. Specifically, the currency of denomination for LCLC is known by construction. By contrast, that for INTLC is not known. To adjust INTLC for exchange rate movements, we use the information about the currency of denomination in the BIS Locational Banking Statistics, as described in Appendix A.2. 
appreciation of the US dollar in the months following the collapse of Lehman Brothers. ${ }^{19}$

Across borrower regions, the effect of these adjustments differs depending on the relative shares of US dollar-denominated claims in total foreign claims. For countries in Asia Pacific and those identified in the CBS as offshore financial centres, where US dollar-denominated claims are dominant, the overall difference between the adjusted and unadjusted series is rather small. By contrast, the adjusted growth rates for claims on Latin America and emerging Europe were less than the corresponding unadjusted rates prior to the crisis, and much higher than the unadjusted rates during the crisis. That is, the unadjusted rates show much larger swings. For the full country sample (top left panel), a regression of the unadjusted rate (dotted black line) on the adjusted rate (red line) yields a statistically significant coefficient of 1.3, indicating that the unadjusted series overstates true movements, and the associated measurement error is not classical. ${ }^{20}$ The fact that the unadjusted series move more than proportionally with the true series means that regressions based on unadjusted data will tend to overstate the importance of any factor correlated with true movements in claims.

\subsection{The stability of local vs. international lending}

The stability of claim stocks during the 2007-09 global financial crisis also depended on the type of claim, with banks' local claims, in particular their local claims in local currencies (LCLC), being more stable in aggregate than their cross-border claims (McCauley et al (2012), McGuire and von Peter (2016)). Cross-border claims, which account for the bulk of international claims (INTLC), are often backed by short-term wholesale funding, which experienced significant disruptions during the crisis (Baba et al (2009)). ${ }^{21}$ Local claims, by contrast, are more often funded with local liabilities (often retail deposits in the same currency), and were relatively unaffected by the disruptions in global wholesale funding markets.

There was considerable heterogeneity across borrower regions in the growth of each type of claim during the crisis, primarily reflecting differences in the types of funding that supported these claims stocks (Graph 4). For example, non-US banks' locally-booked US dollar claims contracted at roughly the same rate as their international claims on the United States (top left panel). As discussed in Section 5 and Box 1 below, the term structure of international claims has bearing on their volatility, since short-term positions are more flexible. The simultaneous contraction in these non-US banks' local US dollar liabilities (not shown) suggests that these local claims were funded by short-term wholesale liabilities rather than by stable retail deposits, which are not directly observable in the CBS data. Similarly, banks' claims of both types on borrowers in the euro area and Japan (top centre and right panels) turned negative during and following the crisis.

Banks' local currency claims on emerging economies proved to be far more stable than their international claims (Graph 4, lower panels). Unlike in the advanced economies, banks' local operations in emerging economies tend to be retail and corporate lending on the assets side, funded by local deposits on the liabilities side. The year-on-year growth in international claims, which are more likely to be funded by less stable shortterm wholesale liabilities, plunged from near $30 \%$ in each region prior to the crisis to $-15 \%$ or lower in the wake of the collapse of Lehman Brothers. In contrast, the growth in these banks' local currency claims slowed much less and actually remained positive up to end-2011 in Latin America and emerging Europe.

The mix of claim types, therefore, affected the stability of the growth rate of overall foreign claims on these regions during the crisis. International claims accounted for an estimated $61 \%$ of banks' total foreign claims on Asia-Pacific in mid-2008, and 56\% of their claims on emerging Europe. By contrast, banks' foreign claims on Latin America were primarily in the form of local claims in local currencies (64\%) reflecting operational requirements imposed by both host supervisory authorities in the region and home supervisory authorities in Spain. $^{22}$

19 The breaks-in-series adjustment (dashed black lines) appears to contribute less when viewed at the aggregate level (top left-hand panel). However, where breaks do occur, they tend to have a larger effect at the bilateral level than do exchange rate movements.

20 If there were no systematic measurement error in the unadjusted line, the coefficient should be one. The $R$-squared from this regression is $89 \%$, and the coefficient on the adjusted series is statistically significant at the $99^{\text {th }}$ percentile, with a $t$-statistics of 22.1 .

21 Wholesale funding, broadly defined, is any funding liability that is not received from an individual person (ie excluding retail deposits). During the crisis, numerous forms of wholesale funding - interbank borrowing, funding from money market funds (MMF), and deposits of foreign exchange reserves - became increasingly expensive or dried up completely.

22 In the CBS (IC basis) used throughout this paper, foreign claims are split into international claims and local claims in local currencies (ie FC $=$ INTLC + LCLC, where INTLC $=$ XBC + LCFC). From a financial stability perspective, local claims in foreign currencies (LCFC) are often funded with a cross-border liability thus making them similar to pure cross-border credit. However, an estimate of the share of pure cross-border claims in foreign claims can be derived from the CBS (UR basis), where foreign claims are split into cross-border claims and local claims in all currencies (ie FC $=\mathrm{XBC}+\mathrm{LCAC}$ ). Using these statistics, the share of pure cross-border claims in total foreign claims on Asia-Pacific in mid-2008 came to 52\%, and those for emerging Europe and Latin America were 43\% and $30 \%$, respectively. 

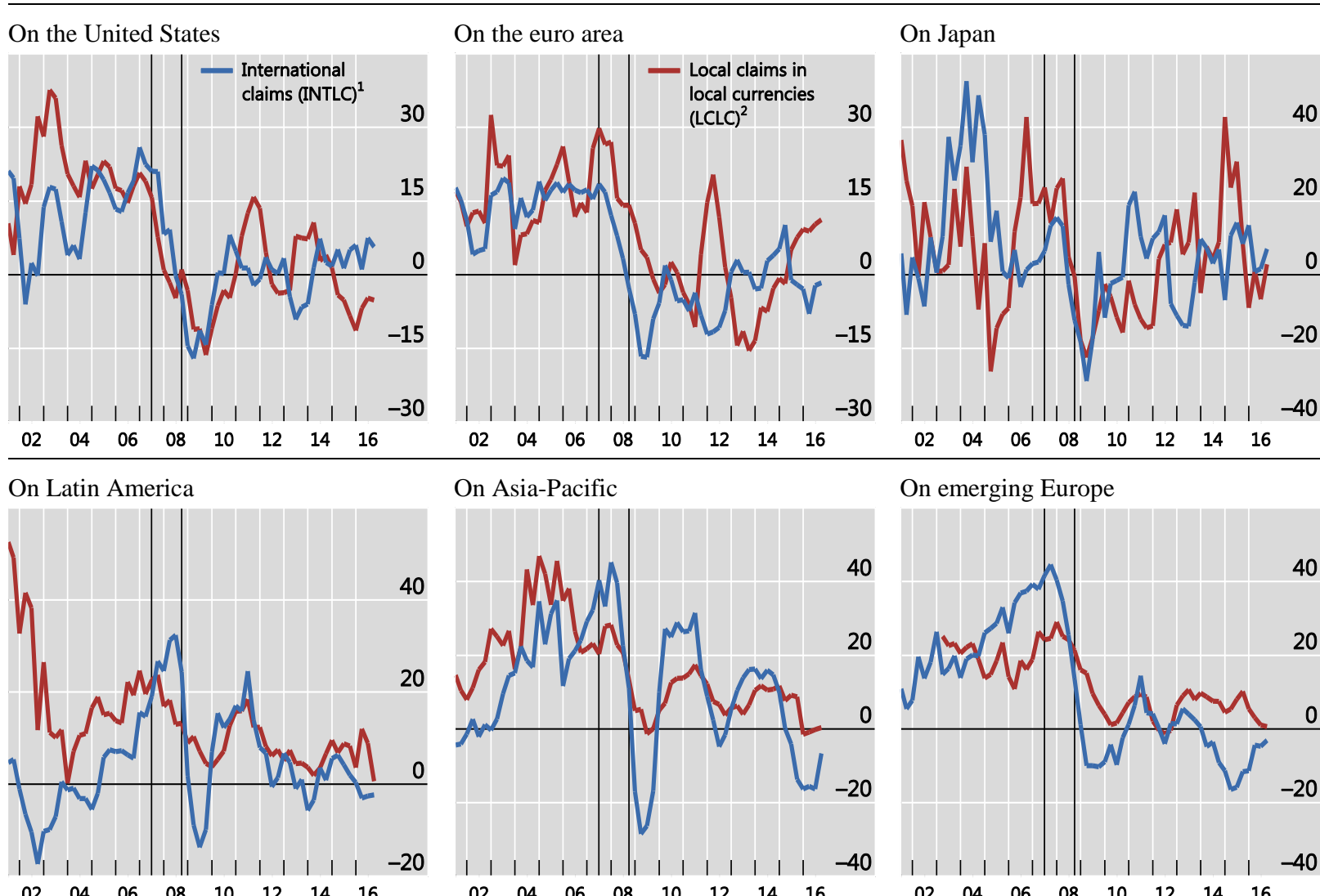

On Asia-Pacific
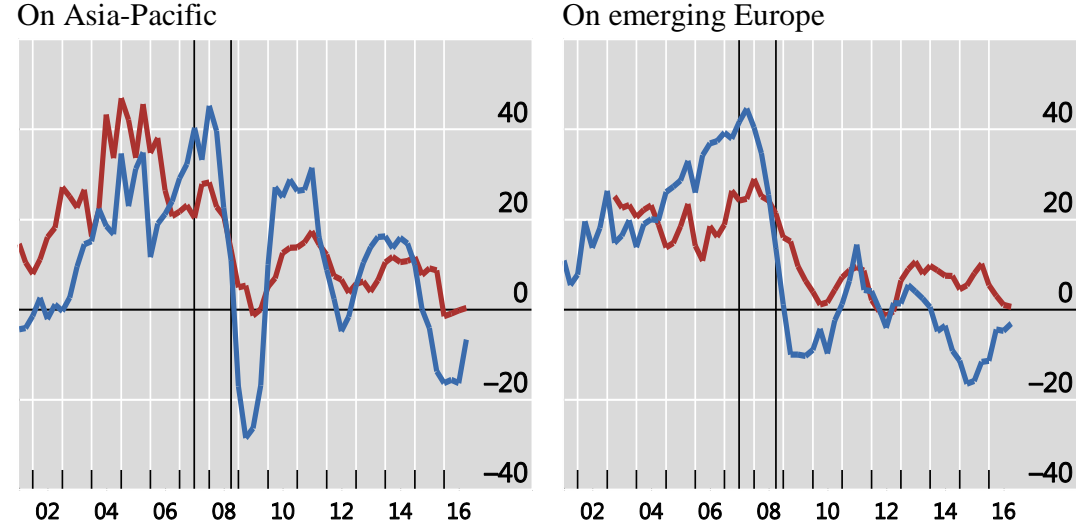

Note: Vertical black lines indicate end-Q2 2007 and end-Q3-2008.

${ }^{1}$ Year-over-year growth in international claims, after adjustments for breaks-in-series and exchange rate movements. ${ }^{2}$ Year-over-year growth in local claims in local currencies, after adjustments for breaks-in-series and exchange rate movements.

Source: BIS consolidated banking statistics (IC basis); BIS locational banking statistics; national data; authors' calculations.

This is clearly reflected in the patterns of growth in total foreign claims on each region in Graph 3 . That is, foreign claims on Asia Pacific, where international (mainly cross-border) claims were dominant, experienced the largest contraction during the crisis. By contrast, the growth in foreign claims on Latin America, which tended to be locally booked and funded, never moved into negative territory. We return to this point in Section 5 , where we relate the size of the estimated shocks to overall foreign claims during the 2007-09 financial crisis to the underlying structure of these claims.

\section{Estimating supply, demand and common shocks}

We now turn to estimation of the shocks using the methodology described in Section 3 on the adjusted yearover-year growth in bilateral foreign claims described in Section 4. We first illustrate how estimates from standard panel regression cannot explain aggregate growth dynamics, particularly when new relationships are important. From there, we show how the growth in foreign claims can be decomposed into supply-side, demandside and common shocks. We decompose the growth in individual banking systems' foreign claims (on all borrower countries) before examining the growth in claims on individual borrower countries.

\subsection{Estimating bank shocks}

Graph 5 illustrates the problems that arise when these data are used in a standard fixed-effects estimation. Importantly, both banking system and borrower country fixed effects are time varying, so that supply shocks and demand shocks in each period can be estimated. Identification is possible in this panel setting since each creditor banking system has outstanding claims with multiple countries, and each country received credit from multiple banking systems. 
The top panels of Graph 5 show the results of applying unweighted OLS to the CBS data. The top left panel shows predicted values of the growth in all banking systems' combined claims on each country (vertical axis) compared to the actual growth in claims (horizontal axis), and the top right panel shows the predicted values of the growth in each banking system's claims on all countries combined (vertical axis) compared to the actual growth observed for each banking system (horizontal axis). Ideally, in both cases, the predicted values should equal (or be close to) the actual values, and thus lie on forty-five degree lines. The closer they are to a forty-five degree line at this disaggregated level, the more of the aggregate growth in total claims that can be explained by the time-varying fixed effects. However, as noted above, such techniques perform poorly when the claim levels are highly concentrated in only a few bilateral pairs, since the estimated "average" effects captured in the coefficients on the fixed effects place too little weight on the subset of observations that contribute most to the growth in aggregate claims. In this case, the predicted values from standard OLS estimation in the top panels are nowhere close to the forty-five degree line.

The predictive power of fixed effects regressions ${ }^{1}$

In per cent

Graph 5

Unweighted observations (standard OLS)
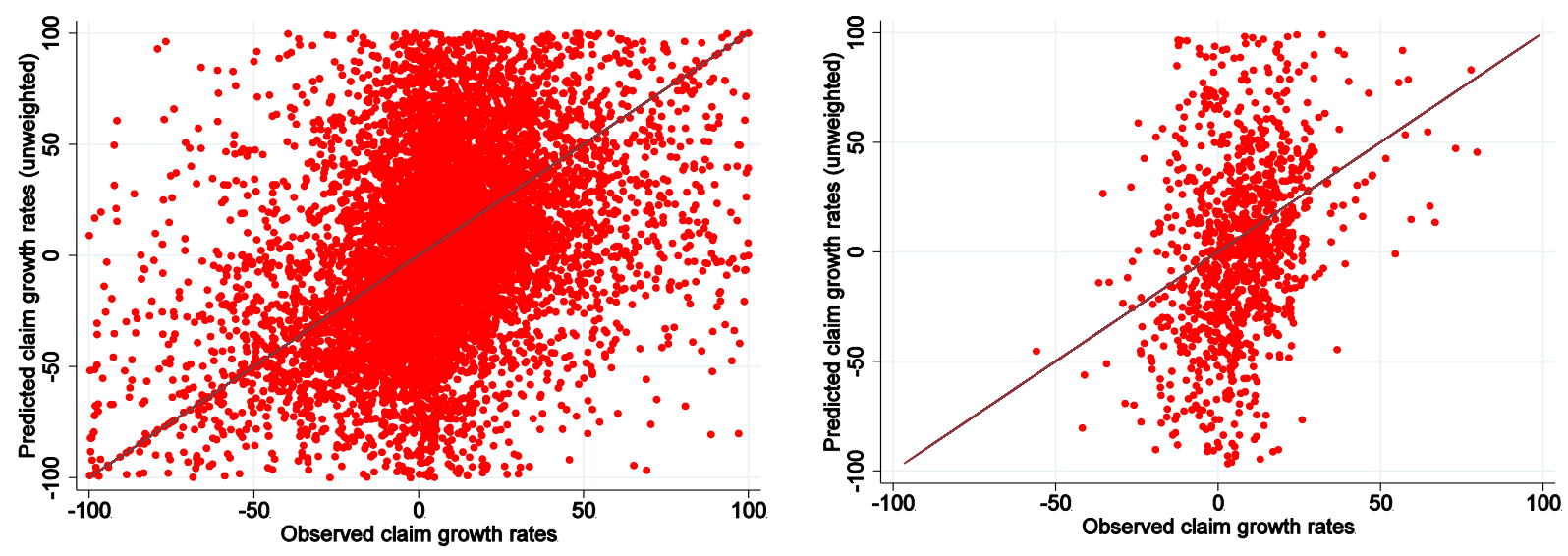

Observations weighted by lagged outstanding claims (Weighted Least Squares) ${ }^{4}$
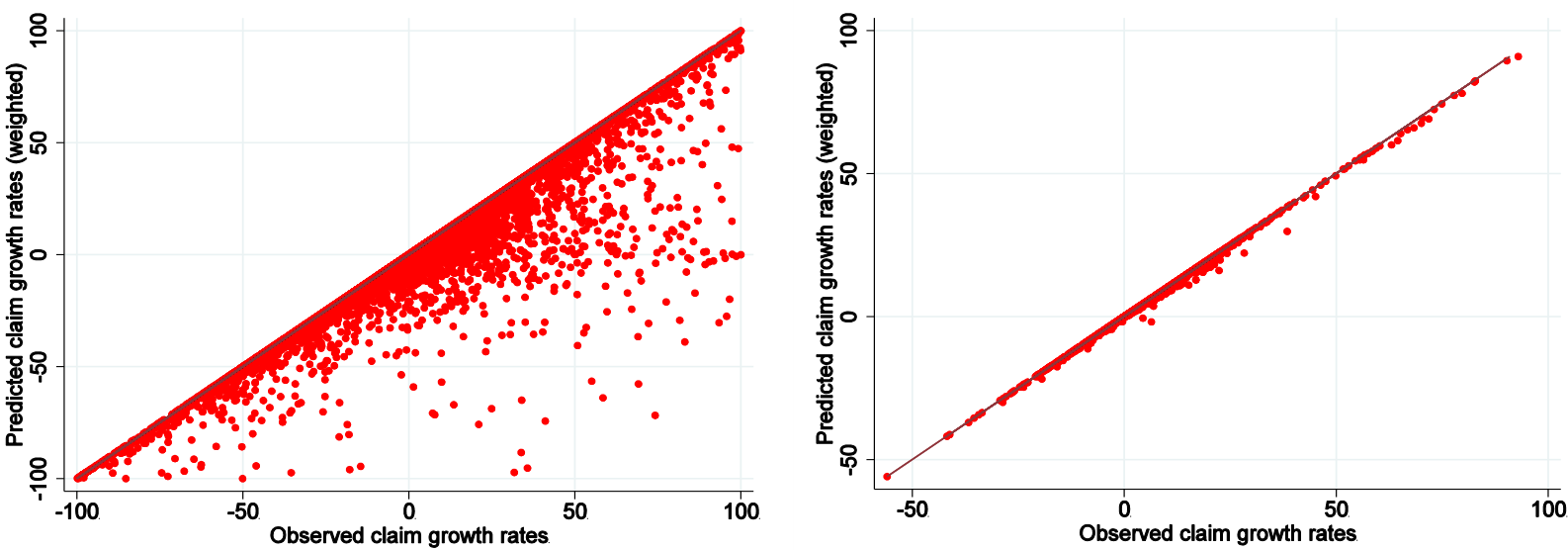

${ }^{1}$ Scatter plots of the actual year-over-year growth (y axis) in foreign claims (adjusted for breaks in series and exchange rate movements) against the predicted growth (x axis) from a regression with time-varying banking-system and borrower-country fixed effects. Outlier values have been dropped in each panel. ${ }^{2}$ Growth in all reporting banking systems' combined claims on individual borrower countries. ${ }^{3}$ Growth in individual banking systems' aggregate foreign claims on all borrower countries. ${ }^{4}$ Fixed effects regression where observations are first weighted by the lagged value of outstanding claim amounts.

Source: BIS consolidated banking statistics (IC basis); BIS locational banking statistics; national data; authors' calculations.

The predictive power of these regressions improves considerably if more weight is given to those observations that contribute most to aggregate growth. The bottom panels of Graph 5 show the corresponding predicted values of the same regression discussed above, but where the observations are weighted by the lagged value of the level of bilateral claims (ie weighted least squares (WLS)). Here, the predicted aggregate growth rates are, overall, much better aligned with the actual rates. Indeed, in a sample where there is no formation of new bilateral links, the predicted values would align perfectly with actual values. However, even this procedure fails to predict growth properly when new bilateral relationships are formed, as is evidenced by the large 
number of points below the forty-five degree line in the lower left panel. Such new bilateral links contribute more to the total growth in claims on a country (lower left panel) than to the growth of the creditor banking system's claims on all countries (lower right panel). Because these observations are dropped in the fixed-effects regressions, the predicted values of aggregate flows understate the true values more so the more new relationships in the data. These plots underscore the importance of using the Amiti and Weinstein methodology to include these observations, and thus exactly reproduce the aggregate growth rates.

\subsection{Accounting for global banking flows}

Graph 6 shows the decomposition of the year-over-year growth in all banking systems' total foreign claims. Red bars indicate the granular supply shocks, or shocks to individual banking systems' claims on all borrower countries. Blue bars indicate granular demand shocks, or those attributable to the borrower country only. These granular shocks are calculated as described in equation (4). Yellow bars depict the common shocks, or the portion of the aggregate growth rates than cannot be separately identified as an idiosyncratic supply or demand shock.

Common shocks (yellow bars) dominate in periods when all banking systems' claims on all countries grow at similar rates, for example during the run up to the global financial crisis. Between 2003 and 2008, virtually all large banking systems expanded their claims on borrowers in all major countries. The common component accounted for most of the growth in claims on advanced economies, offshore financial centres and Latin America during this period. Similarly, it accounted for roughly half of the growth in claims on Asia-Pacific and emerging Europe.

While there was striking similarity in the behaviour of banking in the pre-crisis period, once the crisis hit, the importance of common shocks was almost eliminated. Here we see a clear example of the Anna Karenina Principle: the crisis affected creditor and borrower pairs differently, and at different times. The common component virtually disappears by late-2008, and turns slightly negative in 2009 , indicating that the contraction in claims globally was uneven across banking systems and borrower countries. Indeed, the growth of global claims, given in the top left panel of Graph 6, appears to be as much driven by idiosyncratic supply and demand conditions as by common factors following the financial crisis, and we do not see the common shock reestablish itself until 2011.

Not surprisingly, the importance of granular idiosyncratic components rises as we break the data up by region, because particular borrowers account for a larger share of claims on a region than of global claims. In advanced countries (top centre panel), negative granular supply shocks (red bars) dragged down aggregate claims growth starting in 2008. Similarly, negative granular demand shocks (blue bars) during the crisis further lowered the growth in aggregate claims. This is consistent with the many country-specific explanations for declines in borrowing that varied in severity and sign. For example, the crisis was precipitated by a severe downturn in housing prices in some advanced economies that, once underway, devastated household balance sheets. However, other countries were largely unaffected. Second, the structured finance products that turned toxic during the crisis were overwhelmingly backed by mortgages and other securities issued by obligors located in certain advanced economies (in particular in the United States), and these products sat primarily in the portfolios of banks, pension funds and other asset managers from these advanced economies. Often, these structured products were issued by financial vehicles located in certain offshore financial centres (eg Cayman Islands). The confluence of particular, large banking systems running into trouble because of their claims on particular, large borrower countries led to the downturn, and explains why the common shock gives way to the granular components during the crisis period.

The Anna Karenina Principle was also at work in emerging economies. Prior to the crisis, all emerging regions experienced rapid growth due to a global increase in credit and robust local demand, but after the crisis hit, the patterns across regions diverged as common shocks receded. Negative supply shocks (red bars) contributed to slower growth in claims on all three. Asia-Pacific saw a large decline in growth even though the its creditor banking systems were relatively unaffected. By contrast, robust demand for credit in emerging Europe did not produce significant growth because the this region's creditor banking systems cut back sharply. In other words, the two regions' experiences were largely idiosyncratic. In Section 5.4 below, we explore more formally how the characteristics of the claims contributed to these divergent patterns. 


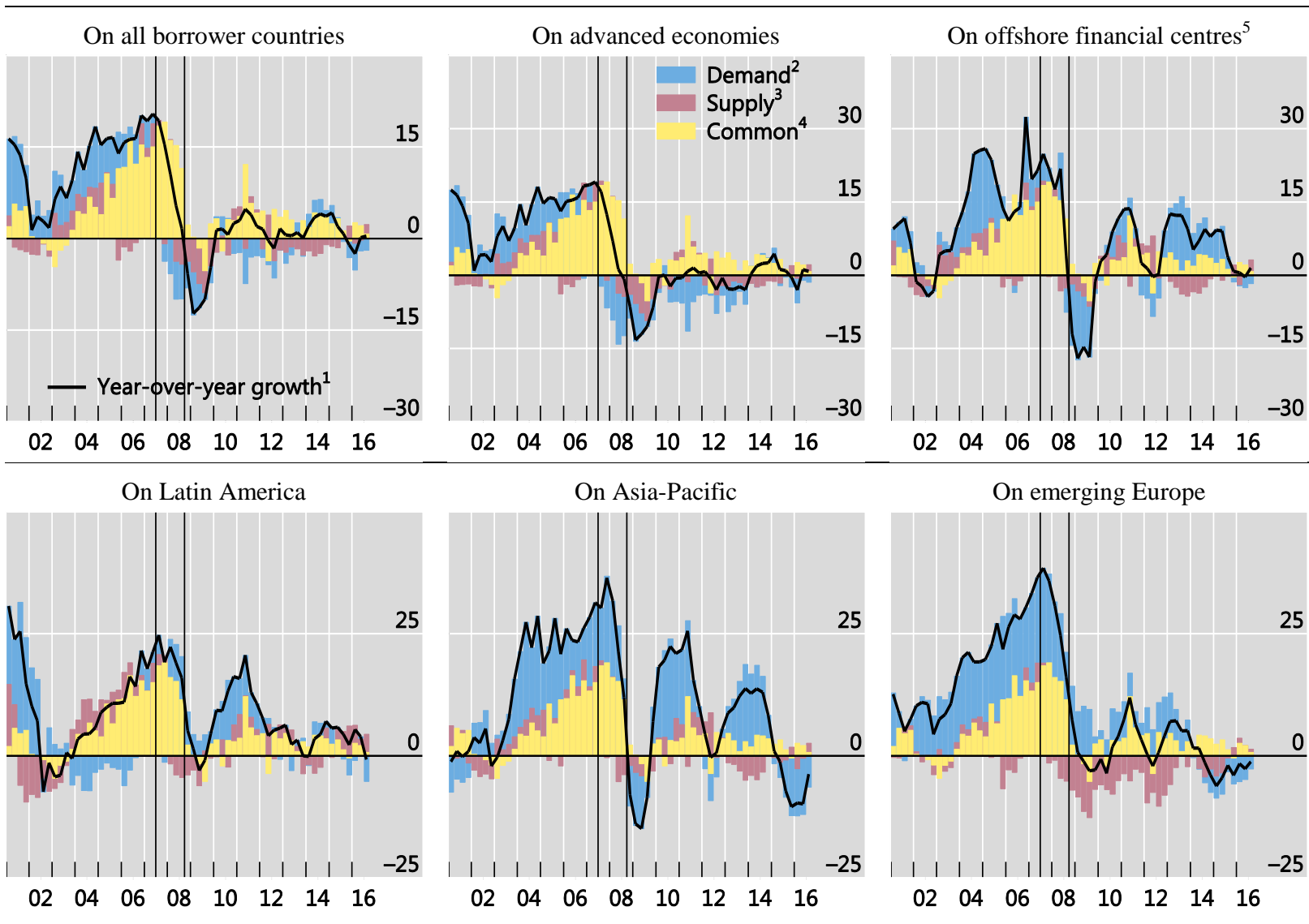

Note: Vertical black lines indicate end-Q2 2007 and end-Q3-2008.

1 Year on year growth in BIS reporting banks' combined foreign claims on the country group indicated in the panel title, adjusted for breaks in series and exchange rate movements. 2 Estimated demand shocks unique to the borrower countries in the country group in the panel title. ${ }^{3}$ Estimated supply shocks to the constellation of banking systems that report claims on the country group in the panel title. ${ }^{4}$ Estimated shocks that are common to all borrower countries and banking systems. ${ }^{5}$ Includes Cayman Islands, Hong Kong, Singapore, Guernsey, Jersey, Isle of Man and other offshore financial centres.

Source: BIS consolidated banking statistics (IC basis); BIS locational banking statistics; national data; authors' calculations.

\subsection{External validity of the banking system shocks}

One way to check if our estimates make sense is to see if they correspond to our priors of which banking systems suffered the most during the crisis. Graph 7 shows how supply and demand shocks contributed to the growth in total foreign claims reported by selected banking systems that were hit particularly hard during the crisis. All of these banking systems registered large negative idiosyncratic supply shocks in the first few quarters after the crisis. Belgian, Dutch, French, German, Swiss, US and UK banks, all of which had invested heavily in structured products in the run up to the crisis, saw much steeper and more sustained contractions in the growth of their foreign claims. These appear as negative supply shocks in Graph 7. The collapse of ABN Amro, a Dutch bank, and Fortis, a Belgian bank, drove the particularly sharp contractions in foreign claims booked by all internationally-active banks headquartered in these countries, and hence the severe negative supply shocks. Similarly, Swiss banks, whose appetite for foreign currency assets swelled their global balance sheets to multiples of Swiss GDP on the eve of the crisis, suffered particularly large losses, prompting a later scaling back of their investment banking operations. 

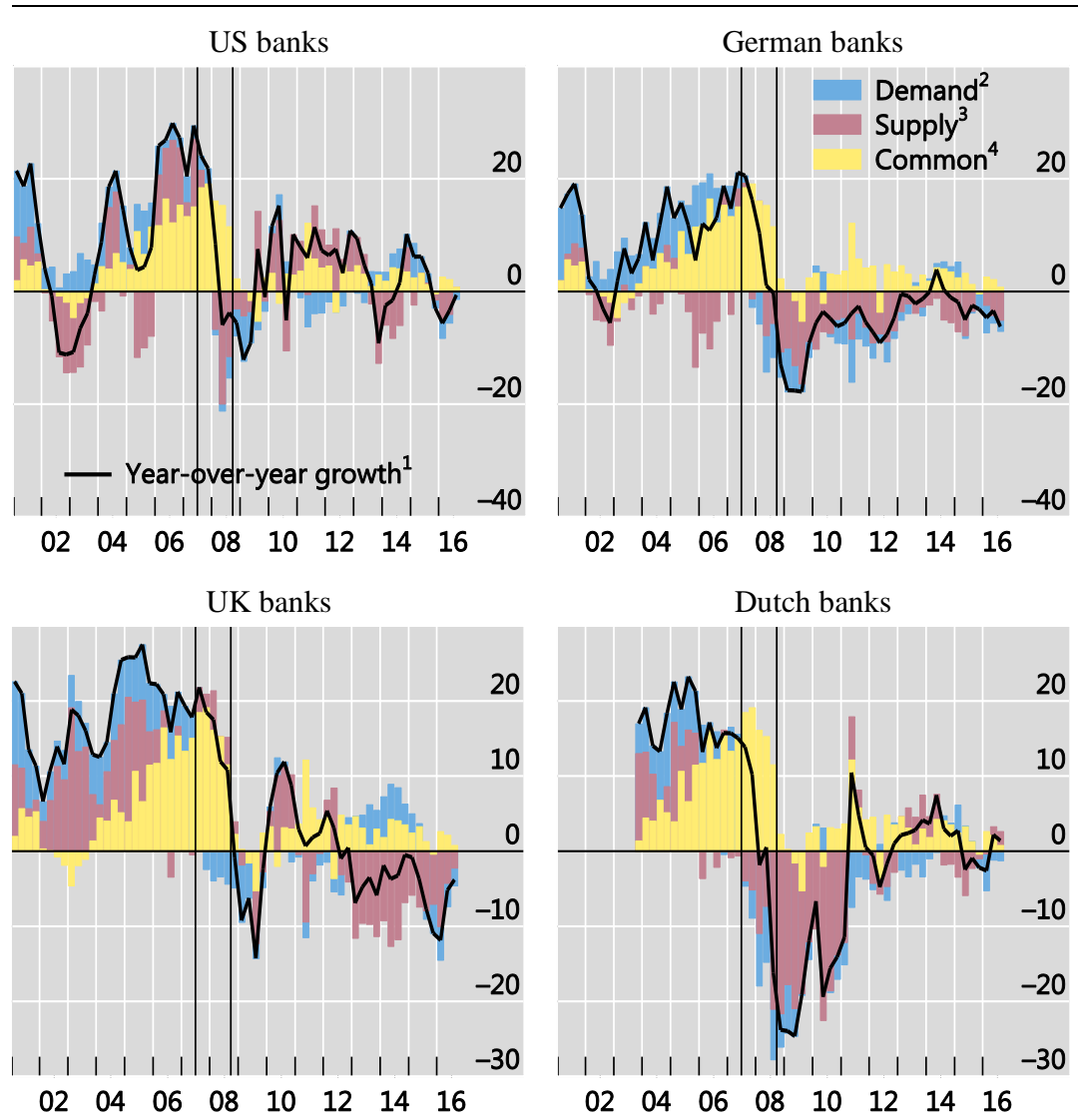

German banks
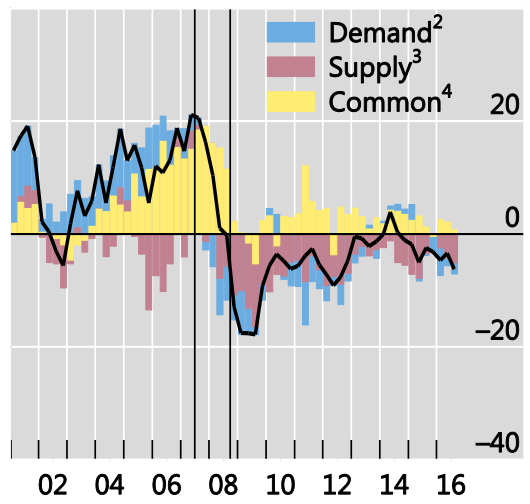

Dutch banks

$\begin{array}{llllllll}02 & 04 & 06 & 08 & 10 & 12 & 14 & 16\end{array}$ $\begin{array}{llllllll}02 & 04 & 06 & 08 & 10 & 12 & 14 & 16\end{array}$
Swiss banks

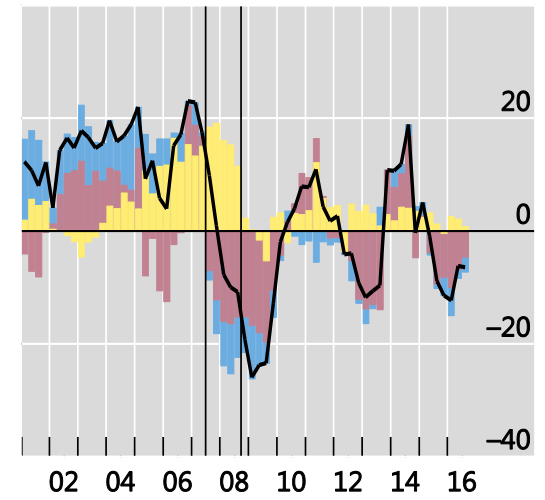

Belgian banks

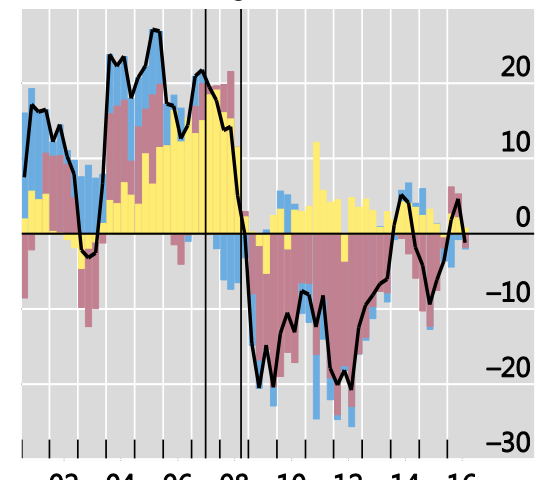

Note: Vertical black lines indicate end-Q2 2007 and end-Q3-2008.

${ }^{1}$ Year-on-year growth in foreign claims of internationally active banks of the nationality indicated in the panel title, adjusted for breaks in series and exchange rate movements. 2 Estimated net demand shocks to the borrower countries on which the banking system in the panel title has outstanding foreign claims. ${ }^{3}$ Estimated supply shocks that are unique to banking system in the panel title. ${ }^{4}$ Estimated shocks that are common to all banking systems and borrower countries.

Source: BIS consolidated banking statistics (IC basis); BIS locational banking statistics; national data; authors' calculations.

While UK banks also suffered losses during the crisis, the estimated supply shocks appear relatively smaller for these banks than for others. This could indicate the bulk of their losses were on positions vis-à-vis counterparties in the home country (United Kingdom), which are not captured in these banks' foreign claims. In addition, at least two of the largest UK banks (Standard Chartered and HSBC) have large operations in Asia, in part insulating these banks from the turmoil in advanced economies.

Graph 8 , by contrast, shows the corresponding figures for banking systems that emerged from the crisis relatively unscathed. (Additional banking systems are presented in Graph A.1 in Appendix 1.) These banking systems exhibited either positive idiosyncratic shocks or no shocks in the key crisis quarters, indicating that they were in a relatively good place to provide credit. Japanese banks, for example, held relatively small amounts of toxic assets. That is, they did not experience a direct negative supply shock and, despite facing funding difficulties during the most intense quarters, their overall claim growth recovered relatively quickly. ${ }^{23}$ Australian, Canadian, Swedish and several smaller Asian banking systems were similar in this regard and also had positive idiosyncratic shocks. Even the Spanish banks, whose home country was particularly hard hit when the unsustainable housing boom came to an end, emerged from the crisis in relatively good shape, which is consistent with their lack of a negative idiosyncratic supply shock. ${ }^{24}$

23. Japanese banks did register a series of large negative idiosyncratic supply shocks in the early 2000s, when many were on the verge of collapse and under regulatory scrutiny.

24 This reflected Spanish banks' reliance on local lending funded by local liabilities in their many host countries across Latin America, which had the effect of insulating them from the disruptions in the funding market in their home country and elsewhere (McGuire and von Peter (2016)). 

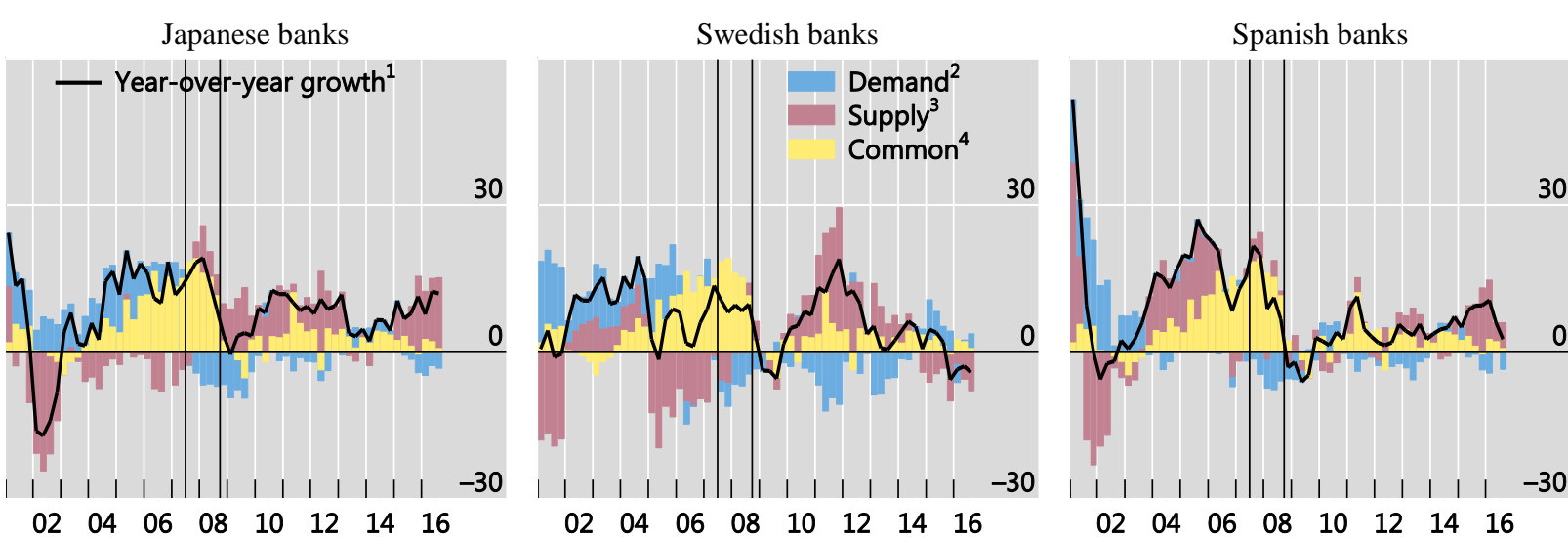

Canadian banks

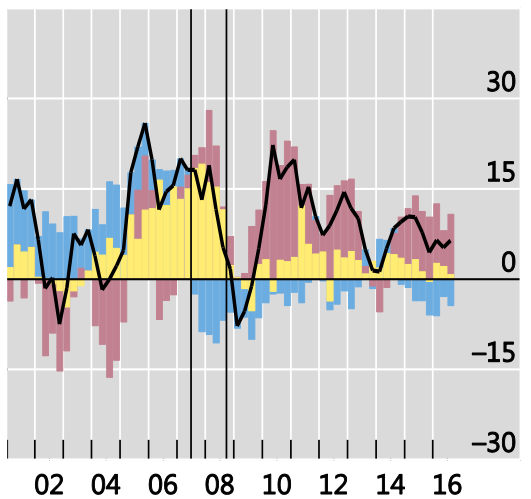

Indian banks

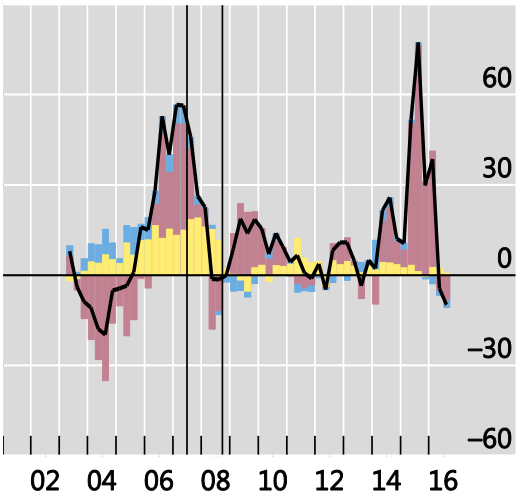

Australian banks

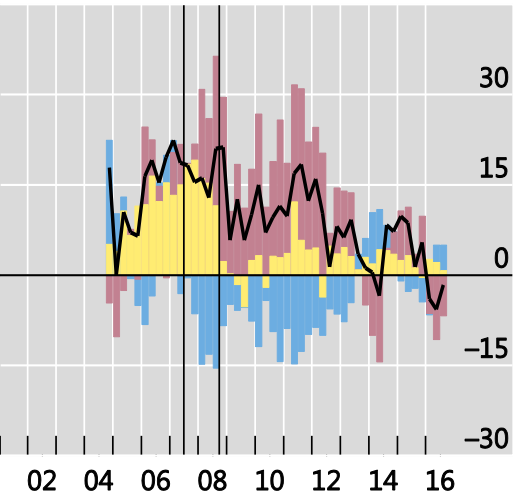

Note: Vertical black lines indicate end-Q2 2007 and end-Q3-2008.

${ }^{1}$ Year-on-year growth in foreign claims of internationally active banks of the nationality indicated in the panel title, adjusted for breaks in series and exchange rate movements. 2 Estimated net demand shocks to the borrower countries on which the banking system in the panel title has outstanding foreign claims. ${ }^{3}$ Estimated supply shocks that are unique to banking system in the panel title. ${ }^{4}$ Estimated shocks that are common to all banking systems and borrower countries.

Source: BIS consolidated banking statistics (IC basis); BIS locational banking statistics; national data; authors' calculations.

To further evaluate the plausibility of the estimated supply shocks across banking systems, we correlate them with outside measures of the losses banks experienced during the crisis. Starting with Peek and Rosengren (1997), we have long known that international banking flows are inversely related to capital-adequacy ratios when banks are insufficiently capitalized. We can verify that the same forces are apparent in our data. In order to show this, we collected data from Bloomberg and SNL Financial on the losses incurred by individual banks between 2008 and 2010, aggregated these to the level of national banking systems, and scaled the totals by the Tier 1 capital of the same set of banks. ${ }^{25}$ As shown in the left panel of Graph 9 , the scaled losses incurred by banking systems are negatively correlated with the average size of their estimated supply shocks during the crisis, implying that those systems that incurred larger losses recorded slower claims growth on all borrower countries. The relationship is highly statistically significant, with an $R^{2}$ of 0.64 , and shows that our estimated supply shocks behave the way we would expect.

A second key transmission channel during the crisis was the dislocations in banks' funding markets. Banks that relied more on wholesale funding and cross-currency swaps instead of deposits found themselves unable to roll over their positions during the most severe quarters of the crisis. Consistent with this, the estimated supply shocks during the crisis are positively correlated with pre-crisis deposit to total-liabilities ratios (Graph 9, centre panel). The regression line has a positive slope (significant at the $90 \%$ level), and an $R$-squared of $21 \%$. That is, those banking systems with a lower share of relatively-stable deposit funding in 2008 experienced relatively larger negative shocks.

25 Loss data are available for only those banking systems shown in the left panel of Graph 9. For each reporting banking system, we assemble the data for the top internationally-active banks headquartered in each country and match these with the list of reporting banks for those countries provided to the BIS by each reporting jurisdiction. 
Finally, the maturity of claims also has bearing on their aggregate stability. Banks are able to reduce outstanding short-term claims simply by not rolling them over, whereas longer-term claims are more difficult to adjust quickly. ${ }^{26}$ In the right-panel of Graph 9, we relate the size of bank supply shocks to a lower-bound estimate of the share of foreign claims that had a remaining maturity of one year or less. ${ }^{27}$ Because the effects of the crisis hit different banking systems in different quarters, their supply shocks arise at different times, and are not always consistently negative throughout the 2007 Q3 - 2009 Q4 window used above. But, if we consider the most severe negative supply shock during that window, we find it is highly correlated with the share of each banking systems' total foreign claims with a short-term maturity. The regression line has a negative slope (significant at the $95 \%$ level), and an $R^{2}$ of $32 \%$.

Supply shocks during the financial crisis (Q3 2007 - Q4 2009)

Graph 9
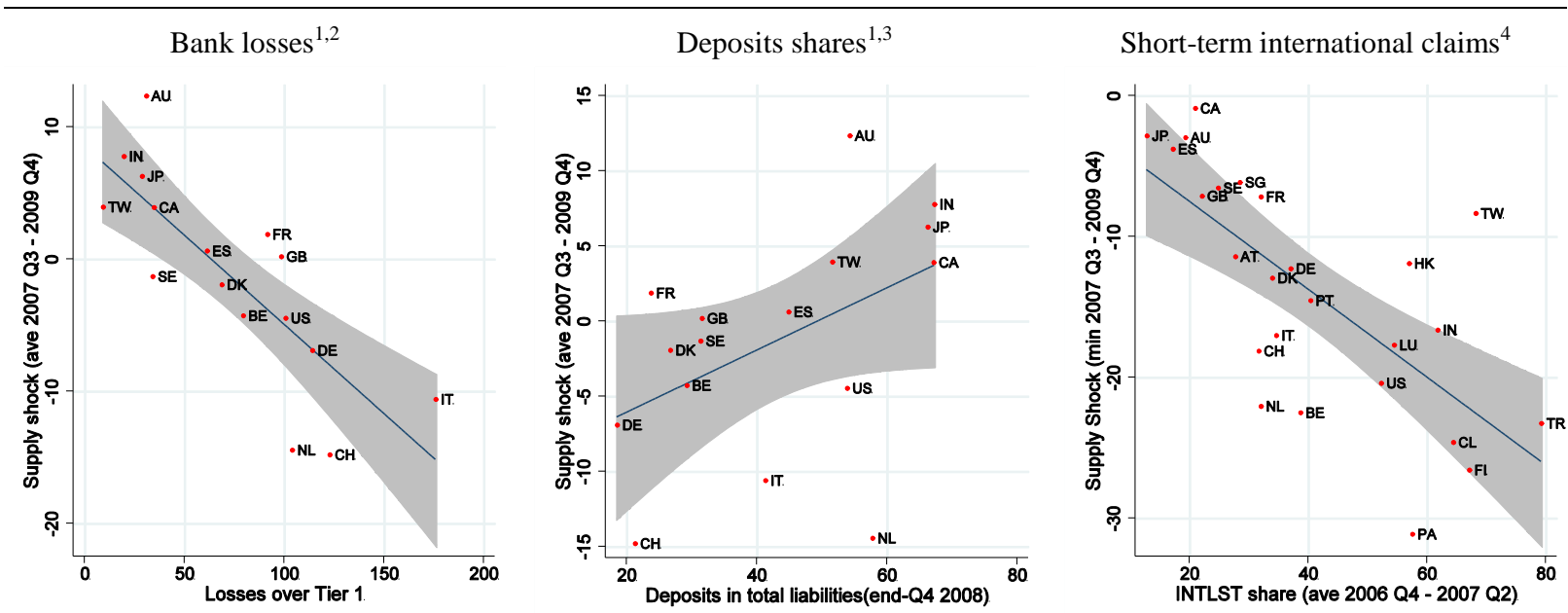
1 The y axis depicts the average value of the supply shock between Q3 2007 and Q4 2009 for the banking system listed in the panels. Grey shaded areas
show the error bands for the linear regression line. 2 The x axis plots each banking system's total credit losses reported between 2008 and 2010 as a
share of the same banks' combined Tier 1 capital as of end-2008. For each individual bank entering these banking system aggregates, total credit losses
are taken to be the larger value from two different sources: the maximum of non-performing loans reported in $2008-10$ (SNL Financial), and reported
credit losses on loans and securities (Bloomberg). 2 Total deposits as a percentage of total liabilities (including domestic banking liabilities) as of end-
2008 , weighted average across the major banks headquartered in the countries shown. 4 The y axis depicts the minimum value of the supply shock
between Q3 2007 to Q4 2009 for the banking system listed in the panels. The x axis shows the share of each banking system's short-term international
claims (INTLST) in total foreign claims on all borrower countries; average over the 2006 Q4 - 2007 Q2 window. Short-term international claims are
those with a remaining maturity of one year or less. Note that there is no maturity breakdown for local claims in local currencies (LCLC).

Source: Bloomberg, SNL Financial; BIS consolidated banking statistics (IC basis); BIS locational banking statistics; authors' calculations.

\subsection{From the perspective of borrower countries}

In this section, we evaluate the growth in foreign claims on individual borrower countries. Here, the growth rates of all banking systems' combined foreign claims on selected countries are disaggregated into the common, supply and demand shocks. Demand shocks (blue bars) are unique to each borrower country while the supply shocks (red bars) for each country are the sum of idiosyncratic shocks to each of the country's creditor banking systems.

\subsubsection{Claims on advanced economies}

While demand shocks always matter for understanding why capital flows to a particular country (as opposed to aggregate flows out of a country), we still can see a weak form of the Anna Karenina Principle at play here as well. Namely, that a borrower's idiosyncratic supply and demand shocks matter much more for particular borrower countries during crisis periods. Graphs 10 and 11 show that the growth in aggregate claims on several large countries in the run up to the financial crisis was driven primarily by common shocks (yellow bars). Most

27 International claims (INTLC) are broken down into three maturity buckets (remaining maturity of less than one year, less than two years but more than one year, and over two years). No maturity breakdown is available for local claims in local currencies, and thus not for total foreign claims (FC). As a result, the ratio used in the right panel of Graph 9 is a lower bound estimate of each banking system's share of foreign claims that are short term. 
striking is the fact that borrowers' idiosyncratic supply shocks, which combine the idiosyncratic shocks to the borrower's creditor banking systems, were largely unimportant in the pre-crisis period.

During and following the 2007-09 financial crisis, however, the common element becomes much less important. In part, this is because foreign claims on particular countries differ in their degree of flexibility. That is, key characteristics like the remaining maturity, counterparty sector and type of instrument all affect the ease with which banks can quickly change their outstanding positions. For example, a bank hit by a balance sheet shock can reduce its outstanding positions simply by not rolling over short-term loans, or by selling liquid securities; long-term loans and illiquid securities make balance sheet adjustment more difficult. ${ }^{28}$ As discussed in Box 1, however, these differences in claim characteristics, which are not explicitly taken into account when estimating the idiosyncratic supply and demand shocks, do not account for the heterogeneity in the differences observed across borrower countries.

\section{Shocks to foreign claims on selected advanced economies}
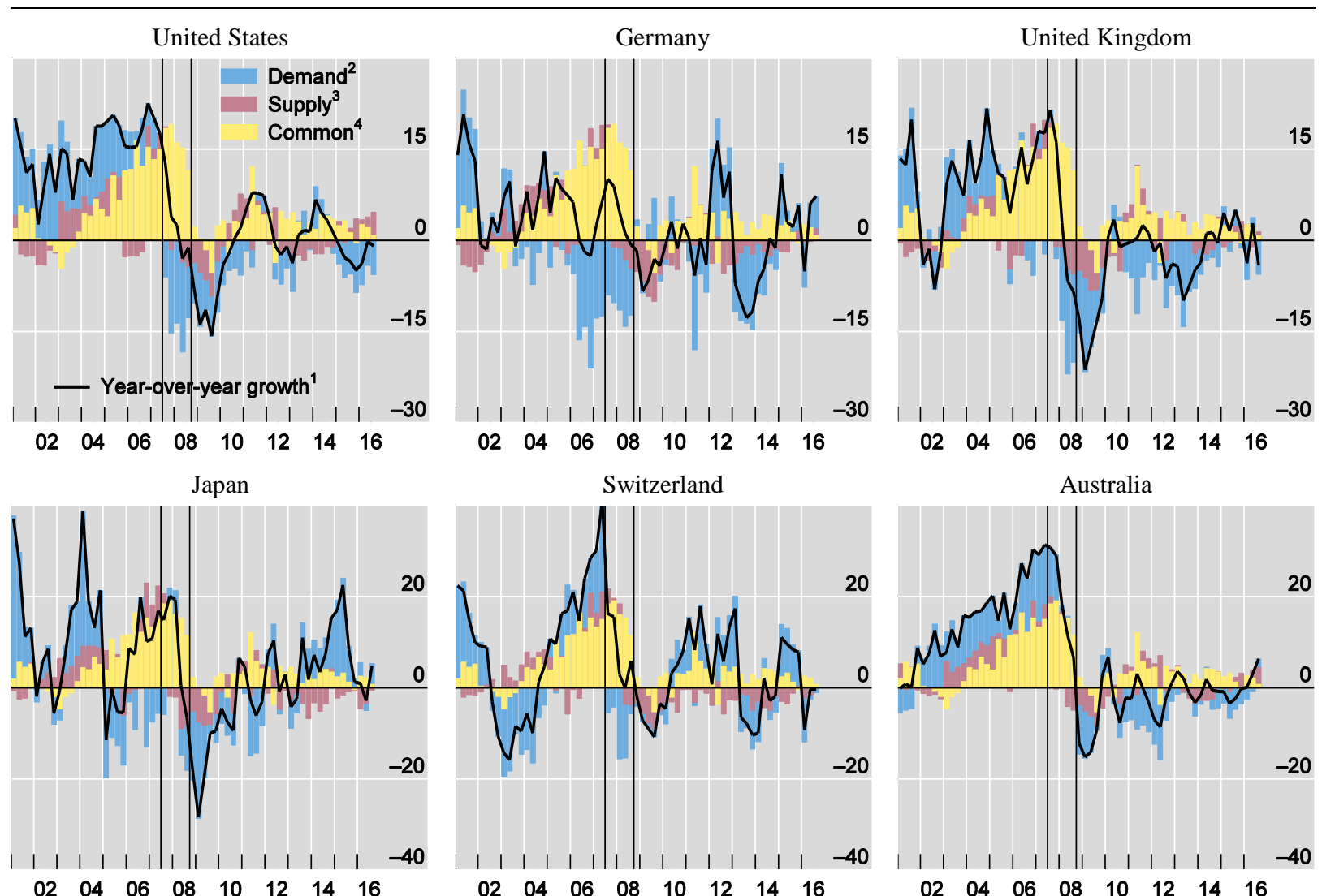

Note: Vertical black lines indicate end-Q2 2007 and end-Q3-2008.

1 Year-on-year growth in foreign claims of all reporting banks on the country listed in the panel title, adjusted for breaks in series and exchange rate movements. ${ }^{2}$ Estimated demand shocks to unique to the borrower country listed in the panel title. ${ }^{3}$ Estimated net supply shocks to the constellation of banking systems that have outstanding foreign claims on the borrower country listed in the panel title. ${ }^{4}$ Estimated shocks that are common to all banking systems and borrower countries.

Source: BIS consolidated banking statistics (IC basis); BIS locational banking statistics; national data; authors' calculations.

The increased importance of the idiosyncratic supply and demand shocks is evident also during the European sovereign crisis which started in 2010. Graph 11 shows the decomposition for selected euro area countries, many of which came under severe strain as this crisis unfolded. Again, the patterns are largely consistent with the patterns in the 2007-09 financial crisis: common shocks accounted for a relatively small share of the growth in foreign claims on these countries. Greece, Ireland, Italy, Portugal and Spain all registered massive negative demand-side shocks (blue bars), consistent with the heightened market scrutiny of their sovereign debt levels. In other words, banks' claims on these countries contracted more rapidly than did these same banks' claims on other countries. That said, several of the creditor banks to these countries were

The contraction in foreign claims on the United Kingdom was amongst the most severe (-22\%), reflecting the fact that London is a financial Hub for both banks and non-bank financial institutions. Short-term cross-border interbank lending to banks in the UK in particular dropped sharply and has yet to recover. 
themselves headquartered in countries that also were under strain. And problems at home may have contributed to slower growth in these banks' foreign claims, including those on other periphery countries. Italian and Portuguese banks, for example, accounted for $10 \%$ and $8 \%$ respectively of the combined foreign claims on Greece and Spain at end-2010. Both banking systems registered negative supply shocks during the 2010-12 window (Graph A.1 in appendix). Such feedback channels contributed to the overall negative supply shocks experienced by the periphery countries in Graph 11.

Shocks to foreign claims on selected euro area countries

In per cent

Graph 11
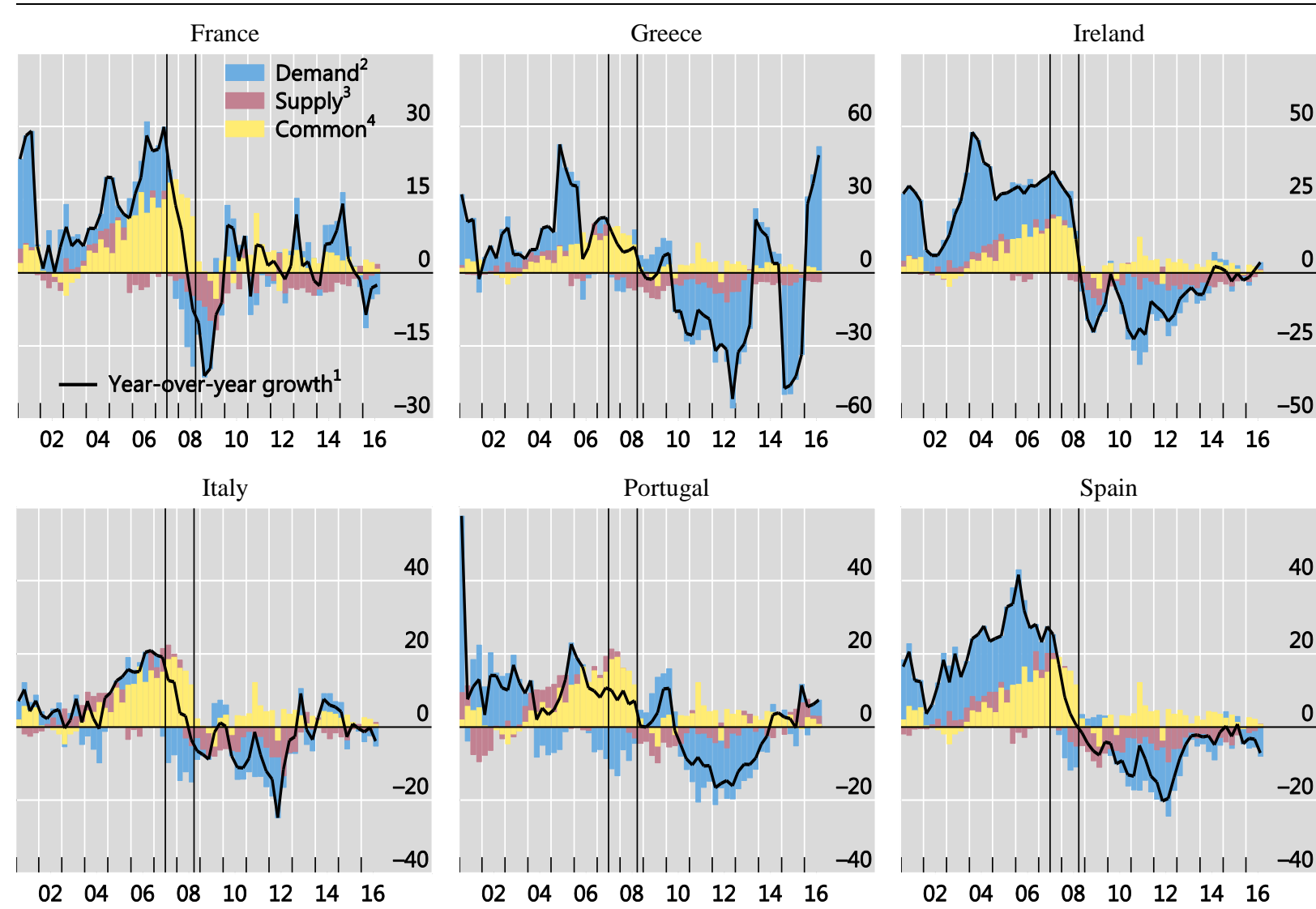

Portugal
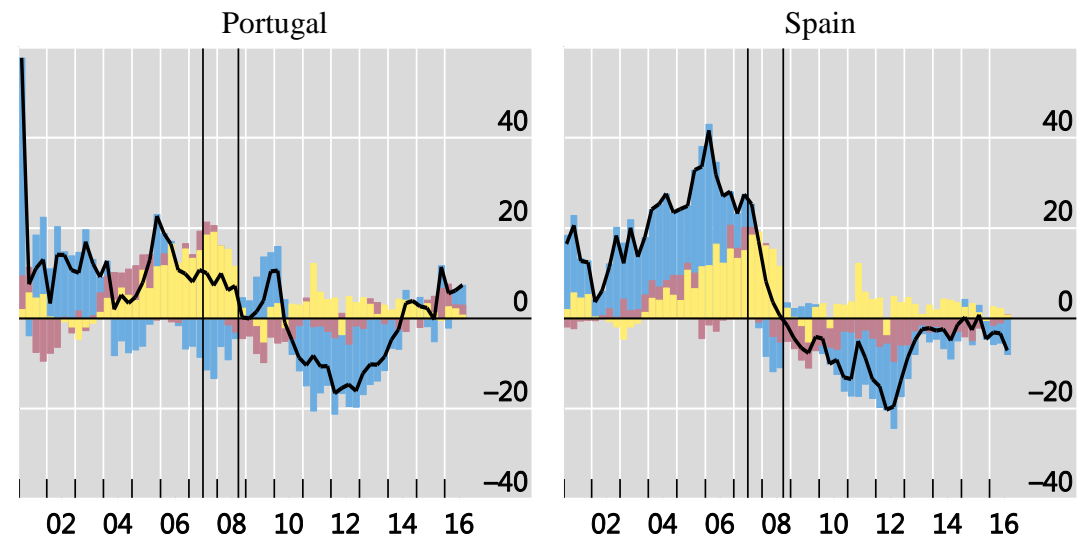

Note: Vertical black lines indicate end-Q2 2007 and end-Q3-2008.

${ }^{1}$ Year-on-year growth in foreign claims of all reporting internationally active banks on the country listed in the panel title, adjusted for breaks in series and exchange rate movements. ${ }^{2}$ Estimated demand shocks to unique to the borrower country listed in the panel title. ${ }^{3}$ Estimated net supply shocks to the constellation of banking systems that have outstanding foreign claims on the borrower country listed in the panel title. ${ }^{4}$ Estimated shocks that are common to all banking systems and borrower countries.

Source: BIS consolidated banking statistics (IC basis); BIS locational banking statistics; national data; authors' calculations. 


\section{Estimated shocks and the maturity of claims}

The estimated supply and demand shocks are quite heterogeneous across borrower countries. One reason for this is that foreign claims differ across countries in terms of the counterparty sector, remaining maturity and instrument, all of which affect the ease with which creditor banks can adjust their balance sheets. For example, banks can more quickly cut back on short-term interbank loans by simply not rolling them over. Similarly, they can quickly sell high quality liquid securities. But longer-term loans, and illiquid securities are far more difficult to take off the balance sheet.

Estimation of the shocks based on overall bilateral foreign claims does not take these claim characteristics into account. Yet the combination of instrument type, maturity and counterparty type for a particular borrower country clearly has an impact on the estimated shocks, as discussed in Section 5.4.2. Borrower countries where a high share of the claims in 2007 were short-term or inter-bank experienced larger contractions in the growth of overall foreign claims. These outsized contractions mean that the common shock accounts for less of the overall change in the growth rate, leaving the estimated demand and supply side shocks to absorb the remaining part. This has bearing on how the estimated shocks should be interpreted, as discussed below.

Table A on the next page provides some concrete examples of where these differences come into play. Column 2 lists all banks' combined foreign claims at end-Q2 2007 on the country listed in the first column. The breakdown by remaining maturity is available only for international claims (column 3); no such information is available for banks' local claims in local currencies. As such, short-term international claims (column 4) provide a lower-bound estimate of the share of short-term claims in total foreign claims (column 5). More than $80 \%$ of the claims on China were international claims (column 5), meaning banks' had a relatively small local presence there. And more than half of these had a remaining maturity of one year or less (column 7). As a result, short-term claims comprised at least $44 \%$ of the total foreign claims on China (column 6), the highest share for all the major countries listed in Table A. Only claims on Caribbean offshore centres, virtually all of which were international, had an estimated share close to China's (39\%). By contrast, the estimated share for Latin America (15\%) and Emerging Europe (24\%) were considerably lower. These differences across regions help explain the heterogeneous growth in foreign claims in Graph 3 in the main text.

These differences have implications for the interpretation of the shocks. To see this, the left panel of Graph A provides a comparison of the common shock estimated for foreign claims (red line) and for short-term international claims only (gold line). Focusing only on short-term claims greatly reduces the outstanding claim amounts, but also reduces the heterogeneity across countries in the flexibility of the claims. With this heterogeneity removed, the dynamics of short-term claims are more likely to be driven by common shocks than by idiosyncratic supply and demandside shocks. During the 2007-09 crisis period, this indeed seemed to be the case: the common shock estimated with short-term claims moved farther into negative territory $(-10 \%)$ than that estimated with foreign claims. In other words, the dynamics of short-term claims during the crisis had a large common component.

\section{Shock estimates for foreign claims and short-term international claims}
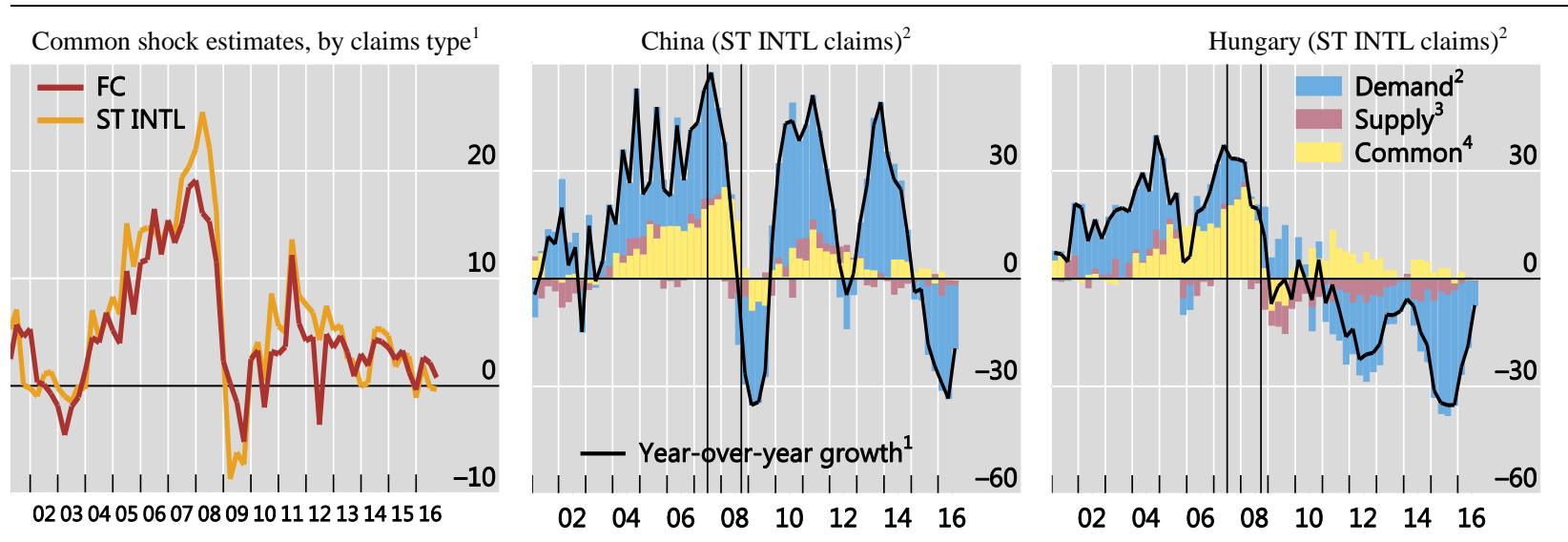

1 The lines show the estimated common shock based on the year-over-year growth in foreign claims (FC, red line) and in short-term international claims only (ST INTL, gold line). ${ }^{2}$ Shock estimates based on the year-over-year growth in ST INTL.

Sources: BIS consolidated banking statistics (IC basis); BIS locational banking statistics; national data; authors' calculations. 
That said, for individual countries, the broad patterns in the demand-side shocks evident in the graphs in the main text are not all that different when estimated with short-term international claims only. The centre and right panels of Graph A (previous page) show the complete set of estimated shocks for China and Hungary. A comparison of these panels to their counterparts in Graphs 12 and 13 in the main text show that shortterm claims contracted more (black lines) during the 2007-09 financial crisis (for China) and during European sovereign crisis (for Hungary) than did foreign claims. However, the overall patterns are remarkably similar, which suggests that the demand shocks we are estimating are picking up the movements in short-term claims. In both cases the estimated demand side shocks dominated during these periods regardless of which underlying claim input is used.

\section{Characteristics of claims on selected borrower countries ${ }^{1}$}

At end-Q2 2007

Table A

\begin{tabular}{|c|c|c|c|c|c|c|c|}
\hline \multirow[b]{2}{*}{ Borrower country } & \multicolumn{3}{|c|}{ Outstanding amounts (USD bln) } & \multicolumn{3}{|c|}{ Shares (per cent) } & \multirow{2}{*}{$\begin{array}{c}\text { Min FC growth } \\
(2007-2010)^{3} \\
\quad(\text { per cent })\end{array}$} \\
\hline & $\begin{array}{l}\text { Foreign } \\
\text { claims } \\
(\mathrm{FC})\end{array}$ & $\begin{array}{c}\text { International } \\
\text { claims } \\
\text { (INTL) }\end{array}$ & $\begin{array}{c}\text { Short-term } \\
\text { International } \\
(\mathrm{ST} \mathrm{INTL)})^{2} \\
\end{array}$ & INTL/FC & ST INTL/FC & ST INTL/INTL & \\
\hline All countries & 27,193 & 17,022 & 8,393 & 63 & 31 & 49 & -12.5 \\
\hline Advanced & 21,833 & 13,540 & 6,823 & 62 & 31 & 50 & -13.2 \\
\hline United States & 6,182 & 2,525 & 979 & 41 & 16 & 39 & -15.7 \\
\hline Euro area & 8,749 & 6,547 & 2,927 & 75 & 33 & 45 & -11.1 \\
\hline United Kingdom & 4,019 & 2,851 & 2,125 & 71 & 53 & 75 & -21.3 \\
\hline Japan & 687 & 334 & 168 & 49 & 24 & 50 & -28.4 \\
\hline Asian offshore & 596 & 294 & 186 & 49 & 31 & 63 & -19.2 \\
\hline Caribbean offshore & 1,129 & 1,109 & 436 & 98 & 39 & 39 & -22.6 \\
\hline Emerging economies & 3,309 & 1,782 & 841 & 54 & 25 & 47 & -6.3 \\
\hline Emerging Europe & 1,009 & 605 & 245 & 60 & 24 & 40 & -3.6 \\
\hline Hungary & 116 & 78 & 23 & 67 & 19 & 29 & -6.4 \\
\hline Poland & 194 & 86 & 23 & 44 & 12 & 26 & 2.6 \\
\hline Czech Republic & 138 & 36 & 13 & 26 & 10 & 37 & -0.8 \\
\hline Latin America & 791 & 269 & 119 & 34 & 15 & 44 & -3.0 \\
\hline Brazil & 248 & 76 & 35 & 31 & 14 & 46 & -10.1 \\
\hline Mexico & 311 & 74 & 22 & 24 & 7 & 30 & -2.7 \\
\hline Chile & 68 & 27 & 14 & 39 & 21 & 52 & -3.8 \\
\hline Asia-Pacific & 1,094 & 645 & 360 & 59 & 33 & 56 & -14.8 \\
\hline China & 203 & 164 & 89 & 81 & 44 & 54 & -25.1 \\
\hline India & 151 & 88 & 47 & 58 & 31 & 54 & -9.2 \\
\hline Korea & 314 & 144 & 88 & 46 & 28 & 61 & -15.0 \\
\hline
\end{tabular}

${ }^{1}$ Claims of all reporting banks on the country/region listed in the first column. Growth rates adjusted for breaks in series and exchange rate movements (Appendix A.2) ${ }^{2}$ Short-term international claims are international claims with a remaining maturity up to and including one year. ${ }^{3}$ Minimum observed year-over-year growth (200710) in foreign claims of all reporting countries on the borrower country listed in the first column.

Sources: BIS consolidated banking statistics; authors' calculations.

\subsubsection{Claims on emerging market economies}

The decomposition of the growth in claims on emerging economies shows that demand shocks played an even larger role for these economies both before and after the financial crisis (Graphs 12 and 13). Between 2000 and 2005, large negative demand shocks are clearly apparent for Argentina and Brazil (Graph 12). Argentina's default in late 2001 and a $11 \%$ contraction in GDP in 2002 is associated with a large negative idiosyncratic demand shock that essentially cut Argentina off from credit markets. Similarly, a drought in Brazil, which is heavily reliant on hydroelectric power, precipitated a severe energy crises in 2001-02, and we see a substantial decline in demand for capital. 


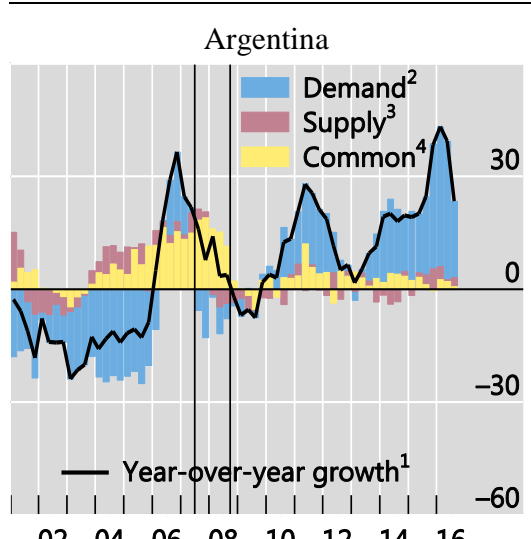

$\begin{array}{llllllll}02 & 04 & 06 & 08 & 10 & 12 & 14 & 16\end{array}$
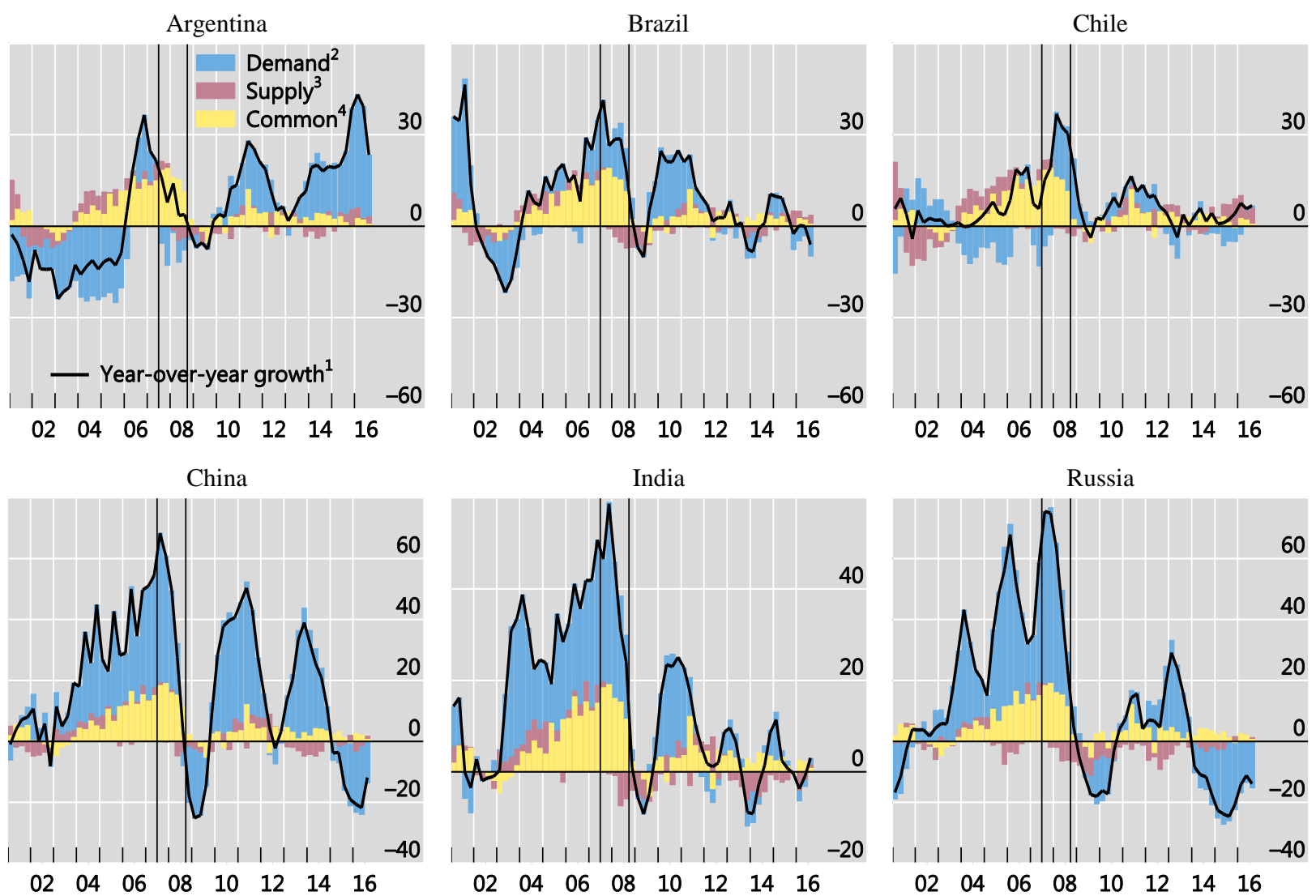

Note: Vertical black lines indicate end-Q2 2007 and end-Q3-2008.

${ }^{1}$ Year-on-year growth in foreign claims of all reporting internationally active banks on the country listed in the panel title, adjusted for breaks in series and exchange rate movements. ${ }^{2}$ Estimated demand shocks to unique to the borrower country listed in the panel title. ${ }^{3}$ Estimated net supply shocks to the constellation of banking systems that have outstanding foreign claims on the borrower country listed in the panel title. ${ }^{4}$ Estimated shocks that are common to all banking systems and borrower countries.

Source: BIS consolidated banking statistics (IC basis); BIS locational banking statistics; national data; authors' calculations.

We also see some of the impacts of idiosyncratic demand factors in China and Russia. After several postcrisis years of rapid economic growth and surging capital flows, emerging economies came under investor scrutiny in 2014 and 2015, prompting massive capital outflows from many countries. Both Russia and China stand out in this regard, as evidenced by the large negative demand shocks in these years (Graph 12). The economic sanctions on Russia introduced in early 2014 following its annexation of the Crimea and the subsequent collapse in oil prices in mid-2014 put significant strain on Russia's fiscal position, prompting creditor banks to significantly reduce their exposures to the country. The growth in foreign claims on Russia, which had reached almost $30 \%$ year-over-year in late 2012, subsequently fell to -25 by end-2015. For its part, uncertainty about the breadth of the slowdown in China's economy sparked dislocations in Chinese equity markets and large capital outflows in 2015. Year-on-year claims growth fell from a high of roughly $40 \%$ in 2013 to $-22 \%$ by mid- 2016 .

Despite the importance of local demand conditions, what is striking is that for most of these countries, idiosyncratic supply shocks hitting each borrower are much more pronounced during the crisis periods. We can see this particularly clearly in Brazil, Russia and India (Graph 12), and in several emerging European economies that were most dependent on troubled banks (Graph 13).

In the year following the 2007-09 crisis, the growth in claims on eastern Europe continued to fall, particular once the European sovereign crisis was underway (Graph 13). The Czech Republic, Hungary and Poland (top panels) all registered large negative supply shocks during this period whereas Estonia, Latvia and Lithuania (lower panels) all registered large negative demand shocks in the following years (bottom panels). ${ }^{29}$ The key to

29 The Baltic countries of Estonia, Latvia and Lithuania were amongst the hardest hit in the world during the crisis, with output contractions of 20-25\% in 2008 and 2009 (Purfield and Rosenberg (2010)). 
understanding these shock patterns is the mix of banking systems that have claims on these countries. The largest creditor banking systems to the Czech Republic, Poland and Hungary in mid-2008 were the major European banking systems (Austrian, Belgian, Dutch, French, German and Italian banks), each of which sustained large negative supply shocks in the wake of the crisis and smaller ones since (Graph 7). By contrast, Swedish banks were by far the dominant creditor banking system to the Baltic countries (Estonia, Latvia and Lithuania). ${ }^{30}$ Swedish banks actually emerged from the crisis relatively unscathed, and the growth in their foreign claims globally returned to pre-crisis levels quickly (Graph 8).

Shocks to foreign claims on selected emerging European economies
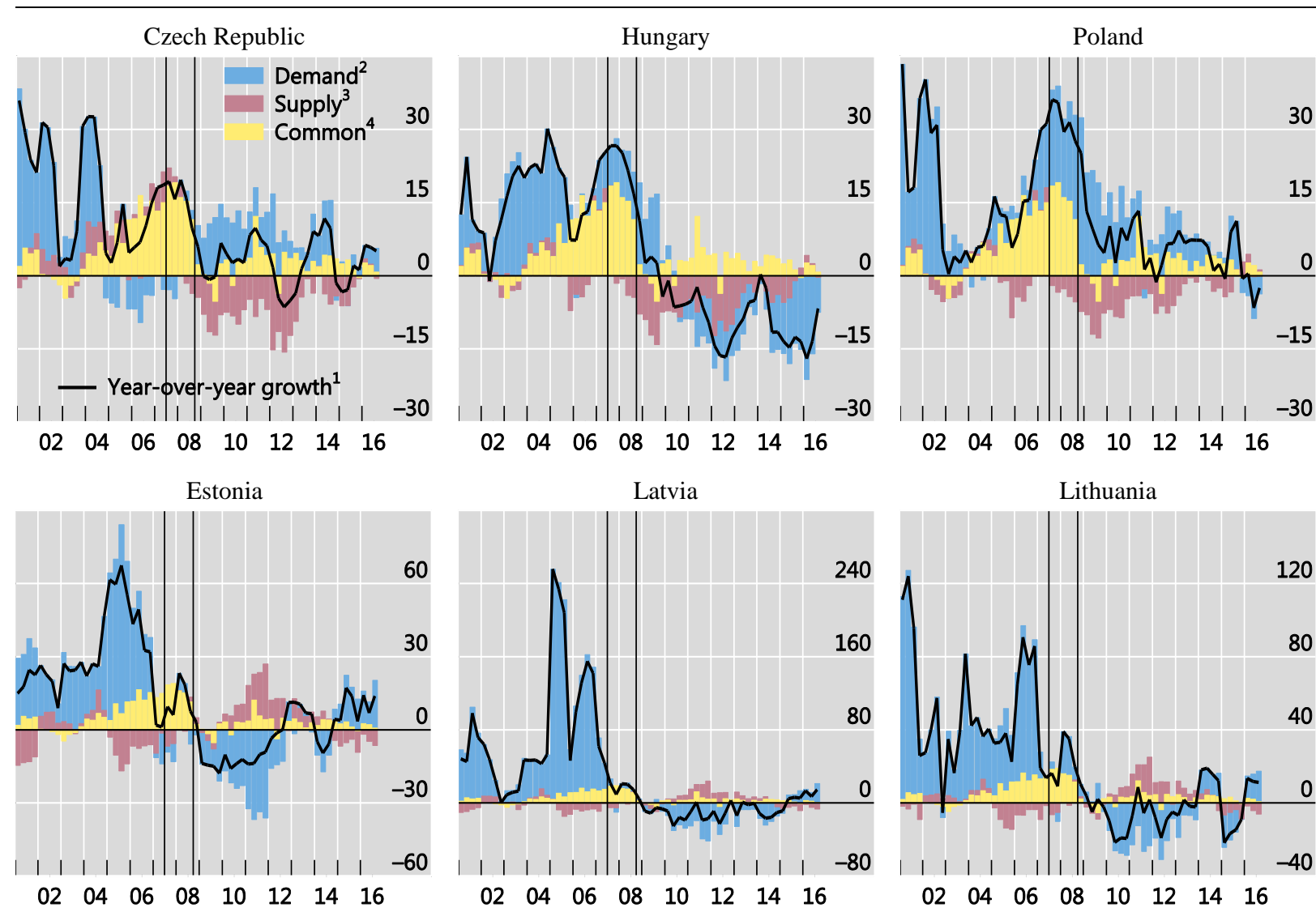

Note: Vertical black lines indicate end-Q2 2007 and end-Q3-2008.

1 Year-on-year growth in foreign claims of all reporting internationally active banks on the country listed in the panel title, adjusted for breaks in series and exchange rate movements. ${ }^{2}$ Estimated demand shocks to unique to the borrower country listed in the panel title. ${ }^{3}$ Estimated net supply shocks to the constellation of banking systems that have outstanding foreign claims on the borrower country listed in the panel title. ${ }^{4}$ Estimated shocks that are common to all banking systems and borrower countries.

Source: BIS consolidated banking statistics (IC basis); BIS locational banking statistics; national data; authors' calculations.

As noted in Section 4, local claims on emerging economies proved to be more stable during the 2007 2009 crisis (Graph 4). In part, this reflects the fact that, in many countries, these local positions were corporate and retail lending backed by local deposits. These pieces of banks' balance sheets were relatively insulated from the rest of their global operations, in particular from the meltdown in structured finance products held in banks' offices in home countries and major financial centres.

It stands to reason, then, that those borrower countries where such local positions were particularly important experienced less severe negative shocks during the crisis period. The data seem to bear this out. Graph 14 examines the top 25 emerging economies, ranked by total foreign claims, which together accounted for almost $90 \%$ of all banks' total foreign claims on all emerging economies in mid-2007. The panels relate the most adverse shocks experienced by each borrower country in the 2007 Q3 - 2009 Q4 crisis window (vertical

30 They extended $\$ 30$ billion to these countries (combined) in mid-2008, compared to the next largest creditor banking system, German banks, at $\$ 500$ million. 
axes) to the local intermediation share (LINT) measured on the eve of the crisis (x-axes). ${ }^{31}$ LINT is a proxy that captures the portion of claims on a country whose funding is insulated from the rest of creditor banks' global operations, and is defined as the share of total foreign claims on a country that are both extended locally in the local currency and funded locally in the local currency. ${ }^{32}$

Estimated shocks and claim structure in emerging economies (Q3 2007-Q4 2009) ${ }^{1}$

In per cent

Graph 14

Shocks and the share of local intermediation (LINT share $)^{2}$

Total shocks (supply + demand)

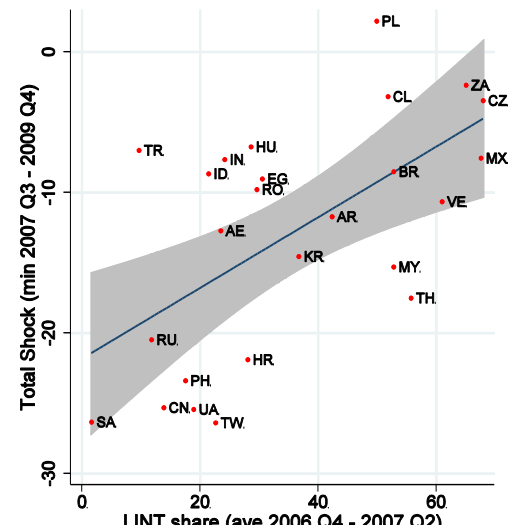

Demand shocks

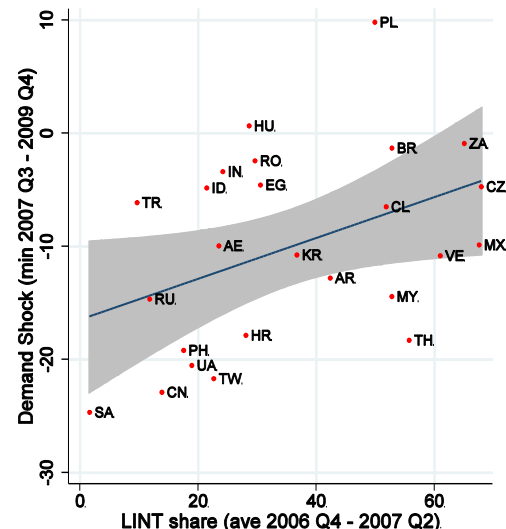

Supply shocks

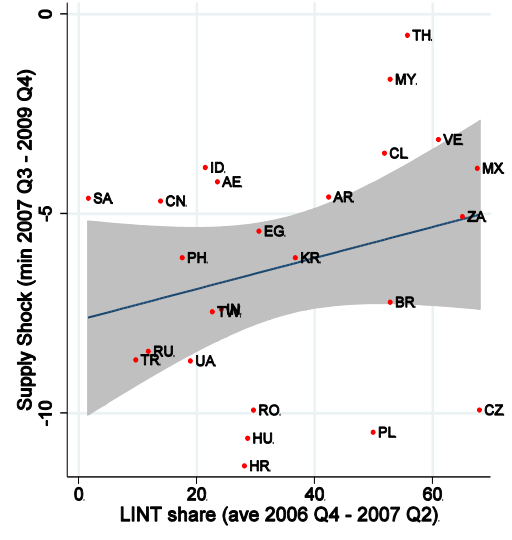

Shocks and the share of claims on other (unaffiliated) banks (Bank share) ${ }^{3}$

Total shocks (supply + demand $)$

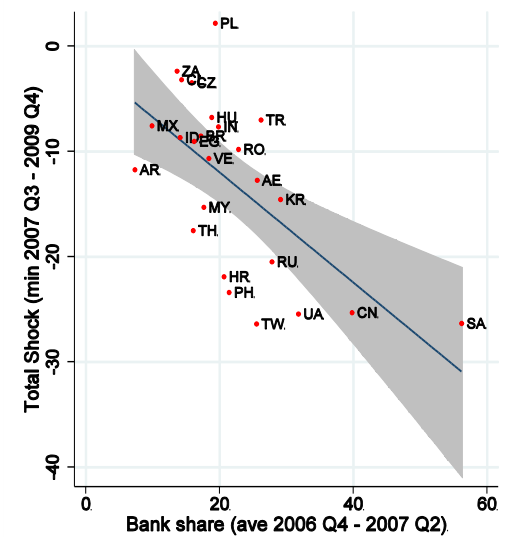

Demand shocks

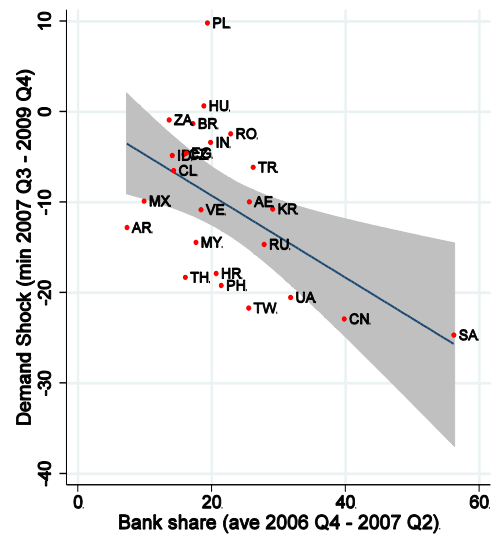

Supply shocks

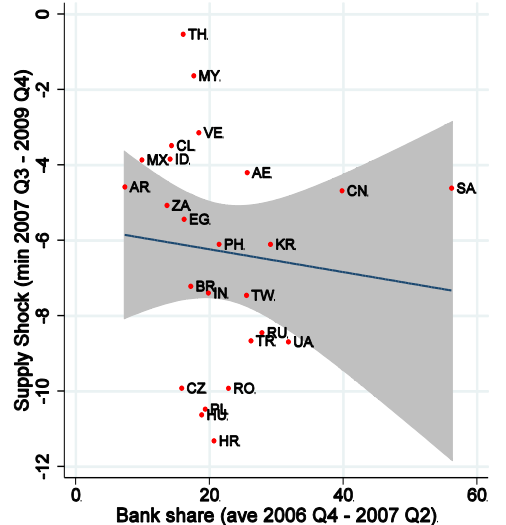

1 The y-axes show the minimum value of the estimated total shock (ie demand plus supply shocks, left panel), demand shock (centre panel), and supply shock (right panel) experienced by each country in the 2007 Q3 - 2009 Q4 crisis window. ${ }^{2}$ For each borrower country, the local intermediation share (LINT) is defined as the sum (across creditor banking systems) of the minimum of each banking system's local claims and local currencies and local liabilities (ie $\min$ (LCLC, LLLC) as a share of all creditor banking systems' total foreign claims the country; average value in 2006 Q4 - 2007 Q2. See footnote 32 in main text. ${ }^{3}$ For each borrower country, the bank share (x-axes) is the share of foreign claims on banks in the country in total foreign claims on all sectors. This share is constructed using the CBS (Ultimate Risk basis), since the sectoral breakdown in these statistics applies to total foreign claims.

Source: BIS consolidated banking statistics (IC basis and UR basis); BIS locational banking statistics; authors' calculations.

31 The y-axes in Graph 14 show the minimum value of the shock measures (ie the smallest positive or the largest negative values) during the crisis window.

32 In many countries, a portion of banks' local claims in local currencies are funded by cross-border inter-office positions, or by nonlocal currencies raised either locally or offshore. By focusing on the local intermediation share, which captures only those local claims that have local currency funding, we arguably better capture the most insulated portions of creditor banks' balance sheets. See McCauley et al (2012) for more discussion. Formally, LINT is defined as the ratio of the minimum of local claims in local currencies and local liabilities in local currencies summed across creditor banking systems $b$ to total foreign claims on the country, or:

$$
L I N T_{c, t}=\frac{\sum_{b} \min \left(L C L C_{b, c, t,}, L L L C_{b, c, t}\right)}{\sum_{b} F C_{b, c, t}} .
$$


The top left panel shows that the lower the LINT share, the more severe was the total shock to a country, where a total shock is defined as the supply and demand shocks combined (ie the actual growth in claims less the common shock). The slope coefficient is significant at the $99 \%$ level, and implies that a 10 percentage point higher LINT share on the eve of the crisis was associated with a maximum negative total shock that was 2.5 percentage points smaller $\left(R^{2}\right.$ of $\left.35 \%\right)$.

Did a higher LINT share help to insulate countries from supply or demand shocks specifically? To answer this question, the top centre and top right panels show the scatter plot separately for these shocks. The most severe negative demand shocks (top centre panel) experienced by each country in the crisis window were smaller for countries with high LINT values. ${ }^{33}$ By contrast, the regression based on the supply shocks (top right panel) falls short of statistical significance.

This pattern is not surprising, and is another example of the Anna-Karenina principle in action. During the crisis window, higher LINT shares helped insulate countries, as is evident in the top left panel. But whether demand or supply shocks offset or compounded each other depended on the mix of banking systems and the structure of their claims on particular countries. The supply shocks are pinned down mainly by the movements in each banking system's global claim portfolio. But, vis-à-vis individual countries, banks' claims are structured differently; more or less cross-border, longer or shorter term, interbank or otherwise (see Box 1 for discussion). Thus, we should expect a higher correlation with the demand shocks. For example, Poland experienced a severe negative supply shock, since many of its creditor banks held toxic assets. But because these banks booked and funded a high share of their claims locally in Poland, the country was less affected by problems in these banks than were countries where short-term cross-border claims were more prominent. In the case of Russia, the two shocks compounded each other, making the total shock more severe.

The lower panels of Graph 14 show a similar pattern for interbank claims on these key emerging economies. A higher share of claims on other (unaffiliated) banks is associated with more severe negative total shocks during the crisis window (left panel). Overall, the slope coefficient is statistically significant at the $99 \%$ level, and implies that a 10 percentage point higher share of claims on banks in a country on the eve of the crisis was associated with a 5.8 percentage point more severe total shock during the crisis window. This share of claims on banks explains a full $47 \%$ of the variation across countries in the size of the total shocks. As with the LINT share in the top panels, it is the demand shocks that drive this result (centre panel); the supply shocks are virtually uncorrelated with the share of interbank claims on these emerging economies.

\section{Conclusion}

It is critical for macroprudential policy makers interested in monitoring cross-border capital flows to understand the drivers of the global credit cycle. But credibly estimating supply- and demand-side drivers has proven to be difficult. Previous studies that rely on panel regression models with fixed effects generally find statistically significant coefficients on a host of plausible drivers. But the models tend to fall short in explaining the aggregate dynamics in the data, as evidenced by small $R^{2}$ values and predicted dependent variables that bear little resemblance to the actual aggregate movements.

This paper exactly decomposes the growth in internationally-active banks' consolidated foreign claim positions. The methodology used here allows for an exact decomposition of claim growth into supply, demand and common factors. As a result, it yields estimated supply, demand and common shocks that, when summed, perfectly match the growth in each banking system's claims on all countries, and all banking systems' claims on any one country.

The shock estimates afforded by this methodology are only as good as the inputs. In order to implement the methodology, we use the BIS Consolidated Banking Statistics, the most comprehensive dataset available on national banking systems' country exposures. Importantly, the CBS, unlike balance of payments data and other residence-based statistics, respect the perimeter of banks' consolidated balance sheets, which means that supply shocks that affect these national banking groups can be credibly estimated. Along the way, the paper demonstrates the importance of two adjustments to the raw CBS data: for breaks in series and for exchange rate movements. Absent these adjustments, the raw data present a very misleading picture of the trajectory of international claims growth.

We document one novel stylized fact, which we term the "Anna Karenina Principle." During normal and boom-periods, the growth rate of banks' foreign claims is largely driven by global common factors and

33 The relationship is statistically significant (at the 95\% level), and the slope of the regression line indicates that a ten percentage point higher local intermediation share on the eve of the crisis is associated with a maximum negative demand shock that was 1.8 percentage points smaller (ie less severe) during the crisis window. 
idiosyncratic local demand. But during crisis periods, growth is driven by idiosyncratic demand and idiosyncratic supply shocks. This pattern is evident for borrower countries as well.

The estimated supply and demand shocks appear plausible across a number of dimensions. The size and direction of the supply shocks across all banking systems during the 2007-09 financial crisis are very highly correlated with the losses suffered by these banks during that period. On the demand side, negative shocks are clearly evident for those European economies that came under strain during the sovereign debt crisis that started in 2010. And they correlate well with idiosyncratic macro-economic shocks (eg sovereign defaults or international sanctions) and recessions in emerging economies. Importantly, those emerging economies where the bulk of creditor banks' claims were both extended and funded locally seemed to suffer from less severe shocks during and following the 2007-09 financial crisis.

The methodology used in the paper provides policy makers with a convenient tool for monitoring global banking activity. By decomposing bilateral growth rates into supply, demand and common shocks, policy makers can quickly ascertain whether rapid increases or decreases in credit to a particular country are driven by systematic changes in the balance sheets of that country's key creditor banking systems (ie supply shocks), or whether they are idiosyncratic for that country (ie demand shocks). 


\section{References}

Amiti, M and D Weinstein (2011): "Exports and financial shocks", The Quarterly Journal of Economics, vol. 126(4), pp. 1841-1877.

Amiti, M and D Weinstein (forthcoming): "How much do bank shocks affect investment? Evidence from matched bank-firm loan data", Journal of Political Economy, forthcoming.

Avdjiev, S, Z Kuti and E Takáts (2012): "The euro area crisis and cross-border bank lending to emerging markets", BIS Quarterly Review, December.

Avdjiev, S and E Takáts (2014): "Cross-border bank lending during the taper tantrum: the role of emerging market fundamentals", BIS Quarterly Review, September.

Avdjiev, S and C Upper (2010): "Impact of the reclassification of US investment banks", box in Highlights of international banking and financial market activity, BIS Quarterly Review, March.

Baba, N, R McCauley and S Ramaswamy (2009): "US dollar money market funds and non-US banks", BIS Quarterly Review, March.

Bruno, V and H S Shin (2014): "Cross-border banking and global liquidity", The Review of Economic Studies, December.

Cerutti, E, S Claessens and L Ratnovski (2017): "Global liquidity and cross-border bank flows", Economic Policy, vol. 32 (89), pp. 81-125.

Cerutti, E (2015): "Drivers of cross-border banking exposures during the crisis", Journal of Banking and Finance, vol. 55, pp. 340-357.

Cerutti, E, G Hale and C Minoiu (2015): "Financial crises and the composition of cross-border lending", Journal of International Money and Finance, vol. 52, pp. 60-81.

Cetorelli, N and L Goldberg (2011): "Global banks and international shock transmission: evidence from the crisis”, IMF Economic Review, vol. 59, no 1.

Fratzscher, M (2012): "Capital flows, push versus pull factors and global financial crisis", Journal of International Economics, vol. 88, pp. 341-356.

Kalemli-Ozcan, S, E Papaioannou and P Fabrizio (2013): "Global Banks and Crisis Transmission”, Journal of International Economics, vol. 89(2), pp. 495-510.

Khwaja, A and A Mian (2008): "Tracing the impact of bank liquidity shocks: evidence from an emerging market", American Economic Review, vol. 98, no 4, pp 1413-1442.

Koepke, R (2015): "What drives capital flows to emerging markets? A survey of the empirical literature", Institute of International Finance working paper.

Lane, P and G M Milesi-Ferretti (2012): "External adjustment and the global crisis," Journal of International Economics, Elsevier, vol. 88(2), pp. 252-265.

Lane, P and G M Milesi-Ferretti (2014: "Global imbalances and external adjustment after the crisis", IMF working paper WP/14/151.

McCauley, R, P McGuire and G von Peter (2012): "After the global financial crisis: From international to multinational banking?", Journal of Economics and Business, vol. 64, no 1, pp 7-23, 2012. Based on "The architecture of global banking: from international to multinational?", BIS Quarterly Review, March 2010.

McGuire, P and N Tarashev (2008): "Bank health and lending to emerging markets", BIS Quarterly Review, December.

McGuire, P and G von Peter (2012): "The US dollar shortage in global banking and the international policy response", International Finance, June 2012. Also published as BIS Working Papers no 291.

McGuire, P and G von Peter (2016): "The resilience of banks' international operations", BIS Quarterly Review, March 2016.

McGuire, P and P Wooldridge (2005): "The BIS consolidated banking statistics: structure, uses and recent enhancements", BIS Quarterly Review, September.

Milesi-Ferretti, G M and C Tille (2011): "The great retrenchment: international capital flows during the global financial crisis", Economic Policy, vol. 26, pp. 289-346.

Peek, J and E Rosengren (1997): "The International Transmission of Financial Shocks: The Case of Japan", American Economic Review, vol. 87(4), September, pp. 495-505). 
Purfield, C and C Rosengerg (2011): "Adjustment under a currency peg: Estonia, Latvia and Lithuania during the Global Financial Crisis 2008-09" IMF working paper 10-213, September.

Rose, A. and M Spiegel (2011): "Cross-country causes and consequences of the 2008 Crisis: international linkages and American exposure", European Economic Review, vol. 55 (3), pp. 309-324.

Takáts, E (2010): "Was it credit supply? Cross-border bank lending to emerging market economies during the financial crisis", BIS Quarterly Review, June. 


\section{A.1 Estimated shocks for smaller banking systems}

\section{Shocks to selected banking systems}

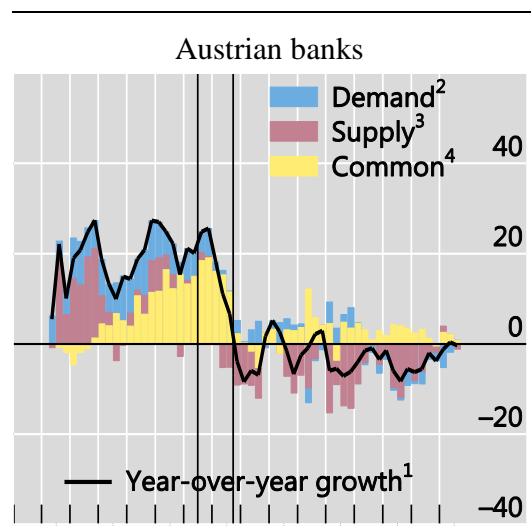

$\begin{array}{llllllll}02 & 04 & 06 & 08 & 10 & 12 & 14 & 16\end{array}$

Portuguese banks

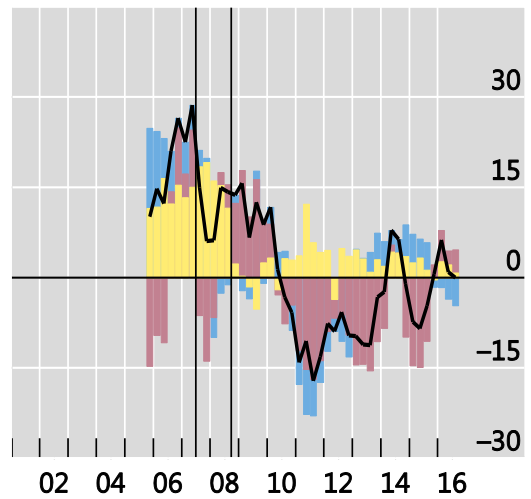

Danish banks

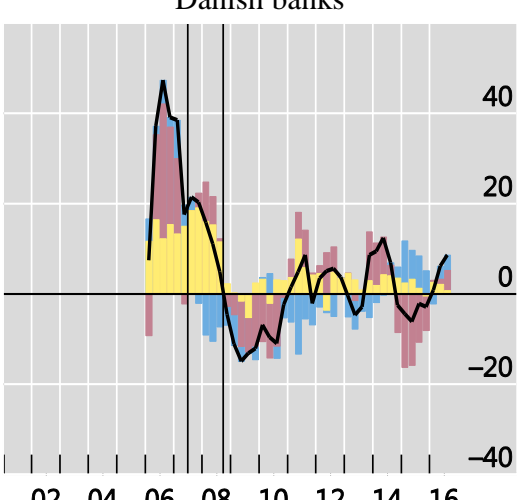

$\begin{array}{llllllll}02 & 04 & 06 & 08 & 10 & 12 & 14 & 16\end{array}$

Singaporean banks

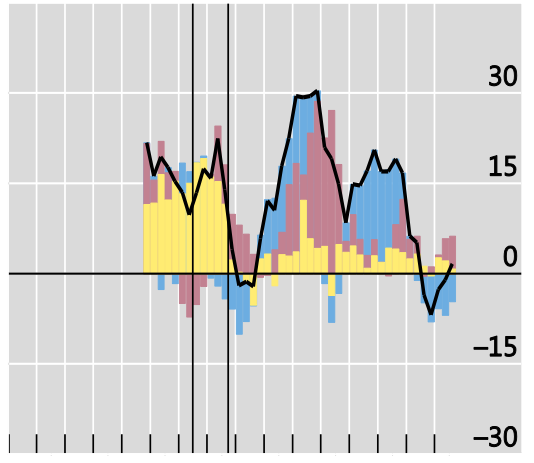

$\begin{array}{llllllll}02 & 04 & 06 & 08 & 10 & 12 & 14 & 16\end{array}$
Italian banks

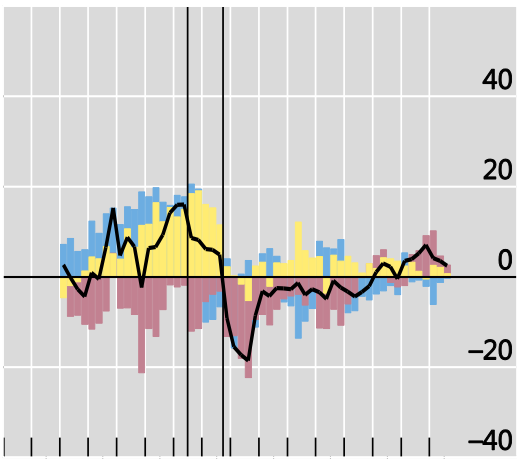

$\begin{array}{llllllll}02 & 04 & 06 & 08 & 10 & 12 & 14 & 16\end{array}$

Taiwanese banks

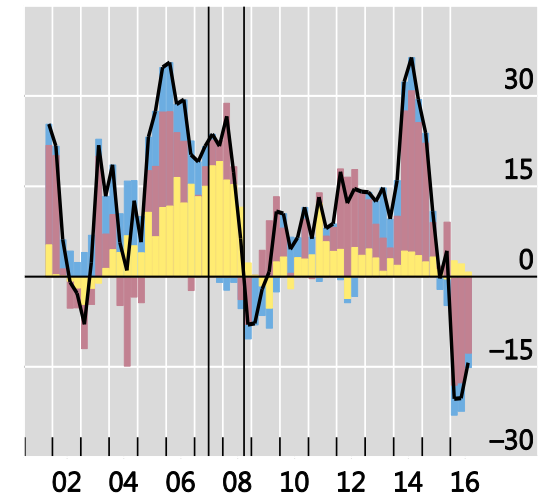

Note: Vertical black lines indicate end-Q2 2007 and end-Q3-2008.

${ }^{1}$ Year-on-year growth in foreign claims of internationally active banks of the nationality indicated in the panel title, adjusted for breaks in series and exchange rate movements. 2 Estimated net demand shocks to the borrower countries on which the banking system in the panel title has outstanding foreign claims. ${ }^{3}$ Estimated supply shocks that are unique to banking system in the panel title. ${ }^{4}$ Estimated shocks that are common to all banking systems and borrower countries.

Source: BIS consolidated banking statistics (IC basis); BIS locational banking statistics; national data; authors' calculations. 


\section{A.2.1 Breaks in series}

Breaks in series caused, for example, by bank mergers or methodological changes lead to jumps in bilateral positions that do not signify that extension or withdrawal of actual credit. Fortunately, the distortions caused by many of the largest of the breaks can be corrected. Reporting countries often provide to the BIS, on a confidential basis, "pre-break" values of outstanding claims from which adjusted bilateral growth rates can be constructed. Where available, we have used these pre-break values in calculating the year-over-year changes in outstanding bilateral claims amounts, which are used as inputs in the empirical analysis.

When there is a known break-in-series but the pre-break data are not available (ie not provided by the reporting jurisdiction), we have two choices; either truncate the sample for the affected banking system, so that the series starts in the quarter after the break; or assume the pre-break growth rates are zero. A priori, it is not clear which procedure is better. Truncating the series has no effect on the estimated shocks in later periods. But the aggregate growth rates (and hence the estimated common and demand-side shocks) prior to the break date are necessarily affected since some observations have been excluded. By the same token, retaining the full series for these banking systems and simply assuming that the growth in claims in the quarter in which the break occurred is zero also introduces error into the estimated shocks. In practice, however, the difference between these approaches is small. In what is presented in the paper, we have truncated the series for certain banking systems where breaks occurred (as is evident in Graphs 7, 8 and A.1).

For one observation for which break-in-series values was not available, we estimated the break value from information in the underlying bilateral positions. For another that reflected the purchase of a subsidiary bank in a particular country, we assumed that the break value was simply full change in the outstanding claim amount.

\section{A.2.2 Exchange rate movements}

Foreign claims on a particular borrower country tend to be denominated in a mixture of currencies. Changes in the relative value of these currencies induce changes in the outstanding stock of claims when expressed in any single currency, here in US dollars. Changes in exchange rates may have economic meaning from the perspective of a reporting banking system, for example in analyses of how currency mismatches across the balance sheet affect bank profitability. However, they are not indicative of the provision or retraction of actual credit, which is the metric needed for the empirical analysis in this paper. In most quarters, exchange rate movements contribute little to the growth in aggregate foreign claims. But, as shown in the main text, extreme exchange rate movements, like those that occurred in the months following the collapse of Lehman Brothers, significantly distort measures of the growth in foreign claims.

The first step in the adjustment is to obtain measures of the share of each currency in foreign claims. Foreign claims can be broken into three pieces: (a) cross-border claims (XBC), (b) local claims in foreign (ie non-local) currencies (LCFC) and (c) local claims in local currencies (LCLC). That is, FC $=\mathrm{XBC}+\mathrm{LCFC}+$ LCLC. In the CBS, XBC and LCFC are reported together as international claims (INTLC $=\mathrm{XBC}+\mathrm{LCFC}$ ), although these claims can be separated (albeit imperfectly) using the BIS Locational Banking Statistics, which has a currency breakdown. We obtain the currency shares for each of these three components separately, and then use them to obtain the shares of each currency in total foreign claims.

The currency shares for these three pieces are obtained as follows:

(a) LCLC: The currency of denomination of LCLC is known by construction. It is simply the currency in use in the borrower country.

(b) LCFC: For many banking-system borrower pairs, the currency shares for LCFC are also known, from the BIS Locational Banking Statistics by Nationality (LBSN). Unlike the CBS, the LBSN track the cross-border claims and local claims in non-local currencies (LCFC) of banks located in a particular location, broken down by the nationality of the banking system. ${ }^{34}$ Thus, for any country that reports the LBSN to the BIS, we know the currency breakdown (USD, EUR, JPY and Other foreign currencies) for each national banking systems' LCFC on the residents of that reporting country.

Currently, more than 40 countries report the LBSN to the BIS, covering more than $95 \%$ of each consolidated national banking systems' global foreign claims. But there are only a few emerging economies that report the LBSN (Brazil, Chile Mexico, South Africa, Chinese Taipei, India,

34 For example, in the LBSN, the reporting country United Kingdom reports LCFC with a currency breakdown separately for the German banks, Swiss banks, French banks, etc that are located there. 
Indonesia, Malaysia and South Korea), and several of them only started reporting after 2000. We do not have actual data about the currency composition of each banking systems' LCFC vis-à-vis those countries that do not report in the LBSN (eg China, Czech Republic, Hungary and Poland). For these countries, we assume that the composition of each banking systems' LCFC is the same as that for all cross-border claims on that country, as described in (c) below. ${ }^{35}$

(c) XBC: Obtaining the currency shares for a consolidated national banking system's cross-border claims on a particular country is the most problematic. The LBSN provide information about the currency composition of banks' cross-border claims booked by their offices in each reporting location. But, critically, they do not reveal the location (country) of the borrower. ${ }^{36}$ The BIS Locational Statistics by Residency (LBSR), by contrast, track the cross-border claims booked by banks offices in each reporting country on individual borrower countries, broken down by currency. But, the LBSR, unlike the LBSN, do not reveal the nationality of the banking system located in each reporting country. In addition, cross-border claims in the LBSR include banks' interoffice positions, which are not included in the CBS and thus not in foreign claims. Cross-border claims in the LBSR are broken down into positions denominated in USD, EUR, JPY, GBP, CHF, the domestic currency of the borrower country, and "Other" foreign currencies.

To obtain the currency shares of each national banking system's worldwide consolidated cross-border claims on a particular country, we take the shares reported in the LBSR for banks of all nationalities and apply these to banks of each nationality. That is, the currency shares of US banks' cross-border claims on Hungary are assumed to be the same as the shares of German, Swiss and other banks' claims on Hungary. For those borrower countries that themselves report the LBSN to the BIS, we make an additional correction to exclude interoffice positions in each currency. Specifically, for these countries, we obtain the currency distribution by taking cross-border claims of all banks in all other BIS reporting countries on all sectors in the borrower country and subtract from this the total crossborder interoffice liabilities reported by banks (of all nationalities) located in the borrower country.

For those borrower countries that do not report the LBSN, we assume that the currency composition of the total international claims in the CBS (INTLC $=\mathrm{XBC}+\mathrm{LCFC}$ ) is simply equal to the currency composition of total cross-border claims (including interoffice) from the LBSR.

With the currency shares for the three components of foreign claims in hand, we are able to estimate the overall currency shares for each consolidated banking system's total foreign claims on each borrower country. The second step in our adjustment is to feed these data series, along with exchange rates, into a chain-linked adjustment that yields the year-over-year growth in foreign claims excluding the effect of exchange rate movements. excluded.

36 That is, they reveal, for example, the currency composition of the cross-border claims of German banks in the United Kingdom, and that of cross-border claims of German banks in every other reporting location. These can be aggregated to reveal the currency composition of German banks' total cross-border claims booked in all locations. But the information about the counterparty country was introduced in the LBSN only in 2013. Thus, they do not reveal the currency distribution of German banks' worldwide consolidated claims on counterparties in any one particular country. 